\title{
Allosteric Control of Gating and Kinetics at P2X Receptor Channels
}

\author{
Baljit S. Khakh,, ${ }^{1}$ William R. Proctor, ${ }^{2}$ Thomas V. Dunwiddie, ${ }^{2}$ Cesar Labarca, ${ }^{1}$ and Henry A. Lester ${ }^{1}$ \\ ${ }^{1}$ Division of Biology, California Institute of Technology, Pasadena, California 91125, and 2University of Colorado Health \\ Sciences Center and Department of Veterans Affairs Medical Center, Denver, Colorado 80262
}

The CNS abundantly expresses $\mathrm{P} 2 \mathrm{X}$ receptor channels for ATP; of these the most widespread in the brain is the $\mathrm{P} 2 \mathrm{X}_{4}$ channel. We show that ivermectin (IVM) is a specific positive allosteric effector of heterologously expressed $\mathrm{P}_{2} \mathrm{X}_{4}$ and possibly of heteromeric $\mathrm{P}_{2} \mathrm{X}_{4} / \mathrm{P} 2 \mathrm{X}_{6}$ channels, but not of $\mathrm{P}_{2} \mathrm{X}_{2}, \mathrm{P}_{2} \mathrm{X}_{3}, \mathrm{P}_{2} \mathrm{X}_{2} /$ $\mathrm{P}_{2} \mathrm{X}_{3}$, or $\mathrm{P} 2 \mathrm{X}_{7}$ channels. In the submicromolar range $\left(\mathrm{EC}_{50}\right.$, $\sim 250 \mathrm{~nm}$ ) the action of IVM was rapid and reversible, resulting in increased amplitude and slowed deactivation of $\mathrm{P}_{2} \mathrm{X}_{4}$ channel currents evoked by ATP. IVM also markedly increased the potency of ATP and that of the normally low-potency agonist $\alpha, \beta$-methylene-ATP in a use- and voltage-independent manner without changing the ion selectivity of $\mathrm{P} 2 \mathrm{X}_{4}$ channels. Therefore, IVM evokes a potent pharmacological gain-of-function

ATP functions as a neurotransmitter in the nervous system (Burnstock, 1972), in which it can mediate (Edwards et al., 1992; Evans et al., 1992; Bardoni et al., 1997; Nieber et al., 1997; Pankratov et al., 1998; Jo and Schlichter, 1999) and possibly modulate fast synaptic transmission ( $\mathrm{Gu}$ and MacDermott, 1997; Khakh and Henderson, 1998a). Furthermore, a class of ion channels exists that is a major target for synaptically released ATP; these are the $\mathrm{P} 2 \mathrm{X}$ receptor channels. $\mathrm{P} 2 \mathrm{X}$ receptors are ATPgated, nonselective cation channels (Surprenant et al., 1995), and they comprise a family of seven distinct subunits that can form functional channels when heterologously expressed (for review, see North, 1996; Ralevic and Burnstock, 1998). Of these, P2X receptor channels are notable because they are widely expressed in the brain (Buell et al., 1996; Collo et al., 1996), they form functional channels that can be both homomeric and heteromeric (Buell et al., 1996; Collo et al., 1996; Seguela et al., 1996; Soto et al., 1996; Le et al., 1998a), and they clearly can be localized to certain neurons (Le et al., 1998b). $\mathrm{P} 2 \mathrm{X}_{4}$ receptors have thus been presumed to be an important target for endogenously released ATP. However, previously there has been no way to specifically probe $\mathrm{P}_{2} \mathrm{X}_{4}$ channels, and this represented a considerable hindrance to investigating both their existence and pathophysiological roles in native systems. As a consequence, the prevalence and

Received April 5, 1999; revised June 1, 1999; accepted June 14, 1999.

This work was supported by a Wellcome Trust (UK) International Prize Fellowship (to B.S.K.), National Institutes of Health Grant NS-11756 and NS-29173, and grants from the Department of Veterans Affairs. Thanks to Dr. I Chessell (Glaxo Wellcome) for providing P2X cDNA clones and Dr. Phillipe Seguela for the P2X cDNA. We thank S. McKinney and $\mathrm{H}$. Li for help with preparation of hippocampal cultures and Xenopus oocytes and W. B. Smith for guidance on use of the Biolistics gene gun.

Correspondence should be addressed to Baljit S. Khakh, Division of Biology, 156-29, California Institute of Technology, Pasadena, CA 91125.

Copyright @ 1999 Society for Neuroscience 0270-6474/99/197289-11\$05.00/0 phenotype that is specific for $\mathrm{P}_{2} \mathrm{X}_{4}$ channels. We also tested whether IVM could modulate endogenously expressed P2X channels in the adult trigeminal mesencephalic nucleus and hippocampal CA1 neurons. Surprisingly, IVM produced no significant effect on the fast ATP-evoked inward currents in either type of neuron, despite the fact that IVM modulated $\mathrm{P}_{2} \mathrm{X}_{4}$ channels heterologously expressed in embryonic hippocampal neurons. These results suggest that homomeric $\mathrm{P}_{2} \mathrm{X}_{4}$ channels are not the primary subtype of $\mathrm{P} 2 \mathrm{X}$ receptor in the adult trigeminal mesencephalic nucleus and in hippocampal CA1 neurons.

Key words: ATP; ivermectin; ion channel; allosteric; modulation; P2X; purinoceptor function of $\mathrm{P} 2 \mathrm{X}_{4}$ channels in brain neurons remained largely uninvestigated.

Many ligand-gated ion channels are allosterically modulated (Li et al., 1997; Changeux and Edelstein, 1998), and such allosteric interactions can be starting points for rational drug design. Moreover, some $\mathrm{P} 2 \mathrm{X}$ receptor channels are modulated by cations, e.g., $\mathrm{P} 2 \mathrm{X}_{2}$ and $\mathrm{P} 2 \mathrm{X}_{3}$ channels by $\mathrm{Zn}^{2+}, \mathrm{Ca}^{2+}$, and $\mathrm{H}^{+}$(King et al., 1997; Stoop et al., 1997; Wildman et al., 1997, 1998; Cook et al., 1998). There is also evidence that an allosteric interaction at P2X 4 channels regulates agonist binding (Michel et al., 1997), and recent work demonstrates that ATP receptor antagonists can also potentiate ATP-evoked currents at $\mathrm{P}_{2} \mathrm{X}_{4}$ channels (Bo et al., 1995; Miller et al., 1998); however, the mechanism(s) and consequences for $\mathrm{P}_{2} \mathrm{X}_{4}$ channel properties remain to be fully explored. Furthermore, such compounds are of limited value to probe $\mathrm{P} 2 \mathrm{X}_{4}$ channels, because they are antagonists of most other ATP receptors, they potently inhibit ATP-hydrolyzing enzymes, and some are chemically impure (see Humphrey et al., 1995).

Ivermectin (IVM) is an agonist of glutamate-gated chloride channels of invertebrates from several phyla (Cully et al., 1994), and this is thought to be its mechanism of action when used clinically as a treatment for river blindness caused by the nematode Onchocerca volvulus (Fisher and Mrozik, 1992; Van Laethem and Lopez, 1996). Recent evidence shows that in addition to its action on glutamate-gated chloride channels, IVM can also allosterically modulate mammalian $\mathrm{GABA}_{\mathrm{A}}$ (Krusek and Zemkova, 1994) and $\alpha_{7}$ nicotinic channels (Krause et al., 1998), and this prompted us to test its actions on P2X channels.

\section{MATERIALS AND METHODS}

Molecular biology. Wild-type $\mathrm{P} 2 \mathrm{X}_{2}, \mathrm{P}_{2} \mathrm{X}_{3}, \mathrm{P} 2 \mathrm{X}_{4}$, and $\mathrm{P} 2 \mathrm{X}_{7}$ cDNAs cloned into pcDNA3 or pcDNA1 were obtained from Glaxo Wellcome (Greenford, Middlesex, UK). cDNAs were linearized at unique restriction sites downstream of the poly(A) tail. The cDNAs were transcribed in vitro 
using the mMESSAGE mMACHINE kit (Ambion Inc., Austin, TX). The capped cRNA was dissolved in DEPC-treated water at a concentration of $\sim 1 \mu \mathrm{g} / \mu \mathrm{l}$ and stored at $-80^{\circ} \mathrm{C}$ until required in $2 \mu \mathrm{l}$ aliquots. Five to $10 \mathrm{ng}$ of cRNA were injected into individual Xenopus laevis oocytes in a volume of $50 \mathrm{nl} /$ oocyte using a Drummond micropipettor (Quick and Lester, 1994); the preparation and maintenance of the oocytes was performed as described previously (Quick and Lester, 1994), and all electrophysiological recordings were made 1-4 d after injection.

Oocyte studies. Two-electrode voltage-clamp recording of oocytes was performed using the Geneclamp 500 amplifier (Axon Instruments, Foster City, CA). Electrodes were pulled (Flaming-Brown type horizontal puller; Sutter Instruments, Novato, CA) from borosilicate glass (Sutter Instruments) and back-filled with $3 \mathrm{M} \mathrm{KCl}$ to yield resistances of $1-2 \mathrm{M} \Omega$. Recordings were made in solution consisting of (in $\mathrm{mm}$ ): $98 \mathrm{NaCl}, 5$ HEPES, and $1 \mathrm{MgCl}_{2}, \mathrm{pH} 7.45$, which was superfused over the oocytes by gravity flow at a rate of $\sim 3 \mathrm{ml} / \mathrm{min}$ (chamber volume was $\sim 300 \mu \mathrm{l}$ ). Solutions containing ATP were applied to the oocyte using a solenoidoperated solution switcher (General Valve Co., Fairfield, NJ); complete solution exchange around the oocyte occurred within $0.5-1.0 \mathrm{sec}$. We used IVM at a concentration of $\leq 10 \mu \mathrm{M}$, because at higher concentrations we occasionally observed some precipitation in physiological solutions. The vehicle for IVM is DMSO. In vehicle controls $1 \%$ DMSO did not affect ATP-evoked currents (control $100 \mu \mathrm{M}$ ATP-evoked current was $-2611 \pm 186 \mathrm{nA}$, whereas in the presence of $1 \%$ DMSO it was $-2789 \pm 69 \mathrm{nA} ; p>0.05 ; n=4$; also see Results). Voltage control of oocytes was maintained using a Digidata 1200 interface and a personal computer running pCLAMP 6 or pCLAMP 7 software (Axon Instruments). Data were filtered at $200-500 \mathrm{~Hz}$ and digitized at three to five times this rate. Current-voltage relation data were filtered at $1 \mathrm{kHz}$ and digitized at $3 \mathrm{kHz}$. All experiments were performed at $20-23^{\circ} \mathrm{C}$.

Human embryonic kidney cells. Human embryonic kidney (HEK) 293 cells were transfected using Superfect (Qiagen, Hilden, Germany), and all recordings were made $24-48 \mathrm{hr}$ later using an Axoclamp 2A amplifier (Axon Instruments). The extracellular recording solution used for mammalian cells comprised (in mM): $147 \mathrm{NaCl}, 2 \mathrm{KCl}, 1 \mathrm{MgCl}_{2}, 2.5 \mathrm{CaCl}_{2}$, $10 \mathrm{HEPES}$, and 10 dextrose, and the pipette solution comprised (in $\mathrm{mM}$ ): $154 \mathrm{NaCl}$ (or $\mathrm{KCl}$ ), 11 EGTA, and 10 HEPES. Whole-cell voltage-clamp recordings were made with $5 \mathrm{M} \Omega$ borosilicate glass electrodes (Sutter Instruments) using methods that are essentially identical to those already described (Evans et al., 1996).

Adult rat brain slices. All methods used were similar to those already described previously for brainstem neurons (Khakh et al., 1997; Khakh and Henderson, 1998a,b) and hippocampal neurons (Dunwiddie et al., 1997; Frazier et al., 1998a,b). Briefly, young (18- to 27-d-old) male Sprague Dawley rats were killed by decapitation, and a vibratome (model 1000; Pelco, Clovis, CA) was used to prepare $300-\mu \mathrm{m}$-thick coronal slices of hippocampus and brainstem. During incubation the slices were submerged at $32-34^{\circ} \mathrm{C}$ in artificial CSF comprising (in mM): $124 \mathrm{NaCl}, 3.3$ $\mathrm{KCl}, 2.4 \mathrm{MgSO}_{4}, 10$ D-glucose, $2.5 \mathrm{CaCl}_{2}, 1.2 \mathrm{KH}_{2} \mathrm{PO}_{4}$, and 25.9 $\mathrm{NaHCO}_{3}$ saturated with $95 \% \mathrm{O}_{2}$ and $5 \% \mathrm{CO}_{2}$ gas. All experiments were performed at $32-34^{\circ} \mathrm{C}$ while the tissue was superfused with buffer at a rate of $2 \mathrm{ml} / \mathrm{min}$. Whole-cell patch-clamp recording was accomplished by using glass pipettes pulled using a Flaming-Brown electrode puller. The resistance of the pipettes was 6-10 $\mathrm{M} \Omega$ when filled with a potassium gluconate-based internal solution, which comprised (in $\mathrm{mM}$ ): $130 \mathrm{~K}$ gluconate, 1 EGTA, $2 \mathrm{MgCl}_{2}, 0.5 \mathrm{CaCl}_{2}, 2.5 \mathrm{ATP}, 0.3 \mathrm{GTP}$, and 10 HEPES, pH 7.25, adjusted to $290 \mathrm{mOsm}$. Cells were visualized with an upright microscope (AxioSkop; Zeiss, Thornwood, NY) equipped with differential interference contrast optics. Puffs $(5-20 \mathrm{msec})$ of ATP (50 $\mu \mathrm{M})$ were applied directly to the cell body via pressure microejection (5-20 psi) from pipettes identical to the recording pipettes, using a Picospritzer II (General Valve, Fairfield, NJ). Inward currents were recorded in neurons voltage-clamped at -50 to $-60 \mathrm{mV}$ using HEKA (Aalen, Germany) software and hardware. Calibrated syringe pumps (Razel, Stamford, CT) were used to add IVM from a concentrated stock solution directly to the superfusion system. Trigeminal mesencephalic nucleus (MNV) neurons were identified by their location (lateral to the locus coeruleus and the fourth ventricle), large pseudomonopolar appearance, and prominent $I_{\mathrm{H}}$ current (Khakh et al., 1997; Khakh and Henderson, 1998b). CA1 pyramidal cells were identified on the basis of their anatomical location, long dendrite projecting into the stratum radiatum, and distinctive electrophysiological characteristics (Dunwiddie et al., 1997; Frazier et al., 1998a,b).

Embryonic hippocampal neurons. Neurons were prepared as described (Li et al., 1998). Hippocampal neuron cultures were transfected with plasmids for $\mathrm{P}_{2} \mathrm{X}_{4}$ and for enhanced green fluorescent protein (EGFP) using the Bio-Rad (Hercules, CA) Helios gene gun. Gold particles coated with plasmids were prepared as recommended by the manufacturer, and the gene gun was pressurized between 60 and 100 psi. Neurons were transfected after $14 \mathrm{~d}$ in culture, and recordings were made $24-48 \mathrm{hr}$ later. Recordings were made using borosilicate glass electrodes of 4-7 $\mathrm{M} \Omega$ resistance. The bath solution was (in $\mathrm{mm}$ ): $110 \mathrm{NaCl}, 5.4 \mathrm{KCl}, 1.8$ $\mathrm{CaCl}_{2}, 0.8 \mathrm{MgCl}_{2}, 10 \mathrm{HEPES}$, and 10 D-glucose, pH 7.4, osmolarity 230 mOsm. Patch pipettes were filled with a solution containing (in $\mathrm{mM}$ ): 100 potassium gluconate, $0.1 \mathrm{CaCl}_{2}, 1.1 \mathrm{EGTA}, 5 \mathrm{MgCl}_{2}, 10 \mathrm{HEPES}, 3 \mathrm{ATP}$, 3 phosphocreatine, and $0.3 \mathrm{GTP}, \mathrm{pH} 7.2,215$ mOsm. Whole-cell voltage clamp was maintained using an Axopatch-1D amplifier controlled by a personal computer running pCLAMP 6 software via a Digidata 1200 interface (Axon Instruments). Data were filtered at $2 \mathrm{kHz}$, digitized at 5 $\mathrm{kHz}$, and recorded on computer for later analysis. Drugs were applied to single voltage-clamped neurons using a U-tube concentration clamp system (Khakh et al., 1995a,b).

Data analysis. Data were analyzed using Clampfit (Axon Instruments) or Origin 5.0 (Microcal Software Inc., Northampton, MA). Data in the text and graphs are shown as mean \pm SEM from $n$ determinations as indicated (always more than four experiments). All current-voltage relations shown in the figures are leak-subtracted. The ratio of $\mathrm{NMDG}^{+}$ to $\mathrm{Na}^{+}$permeability was calculated for control ATP-evoked currents and those in the presence of IVM using the relation,

$$
\frac{p \mathrm{NMDG}^{+}}{p \mathrm{Na}^{+}}=\exp \left(\frac{\Delta E_{\mathrm{rev}} F}{R T}\right)
$$

where $p \mathrm{NMDG}^{+}$is the permeability to $\mathrm{NMDG}^{+}, p \mathrm{Na}^{+}$is the permeability to $\mathrm{Na}^{+}, \Delta E_{\text {rev }}$ is the shift in reversal potential, and $F, R$, and $T$ have their usual meaning (Khakh et al., 1999). Concentration-effect curves were fitted where appropriate, as indicated, to the Hill equation of the form,

$$
y=\left(\frac{1}{1+\left(\frac{\mathrm{EC}_{50}}{[A]}\right)^{n_{\mathrm{H}}}}\right),
$$

where $y$ is current evoked by ATP, $\mathrm{EC}_{50}$ is the response producing $50 \%$ of the maximal response, $n_{\mathrm{H}}$ is the Hill coefficient, and $[A]$ is the concentration of ATP. Membrane capacitance was determined from the capacitive transients produced by $5-10 \mathrm{mV}$ steps of $>200 \mathrm{msec}$ duration using the membrane test capability of pCLAMP 7 (Axon Instruments). Mean data in Figure $3 A$ were fitted to exponential functions (Origin 5.0) to determine time constants for association $\left(\tau_{\text {on }}\right)$ and dissociation $\left(\tau_{\text {off }}\right)$. The equilibrium dissociation constant $\left(k_{\mathrm{d}}\right)$ for the receptor-IVM interaction was determined by considering the interaction of IV M with $\mathrm{P}_{2} \mathrm{X}_{4}$ channels by the following reaction scheme:

$$
A+R \underset{k_{-1}}{\stackrel{k_{+1}}{\rightleftarrows}} A R,
$$

where

$$
\frac{1}{\tau_{\mathrm{on}}}=k_{+1}[A]+k_{-1}, \quad \frac{1}{\tau_{\text {of } \mathrm{f}}}=k_{-1}
$$

and

$$
k_{\mathrm{d}}=\frac{k_{-1}}{k_{+1}}
$$

where the forward binding rate constant is $k_{+1},[A]$ is the concentration of IVM used, and $k_{-1}$ is the rate constant for dissociation. Total charge transfer during ATP-evoked currents was determined by integration of the voltage-clamp records. In some of the figures background noise has been minimized in the original traces by use of a Savitsky-Golay digital smoothing paradigm (Origin 5.0). Statistical tests were performed using the paired or unpaired Student's $t$ test, as appropriate, and $p<0.05$ was taken to indicate significance. 

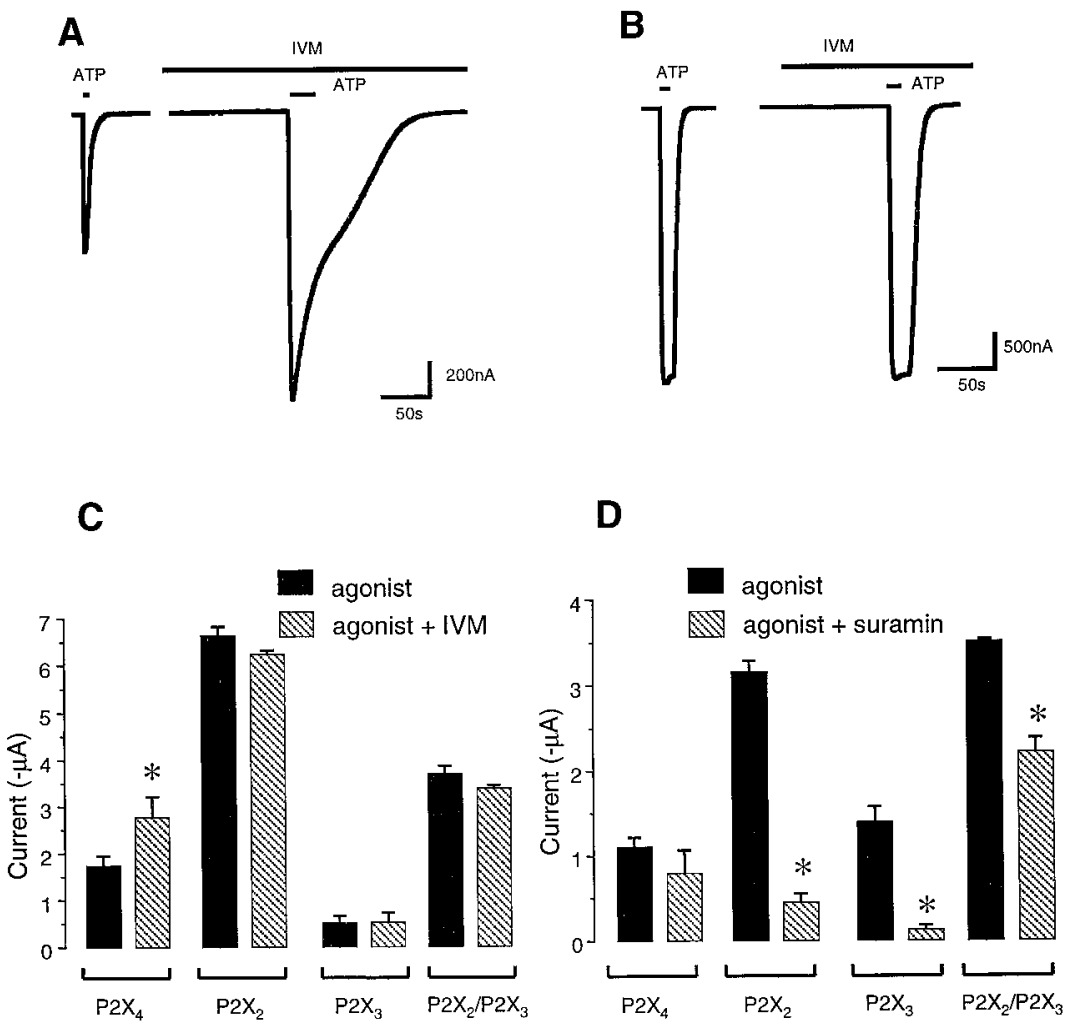

Figure 1. IVM potentiates $\mathrm{P} 2 \mathrm{X}_{4}$ but not $\mathrm{P} 2 \mathrm{X}_{2}$ or $\mathrm{P} 2 \mathrm{X}_{3}$ channel currents. $A$, Representative recordings of currents mediated by $\mathrm{P}_{2} \mathrm{X}_{4}$ channels expressed in oocytes. Left trace, $100 \mu \mathrm{M}$ ATP-evoked current before and after (right trace) addition of IVM $(10 \mu \mathrm{M})$; IVM potentiates the amplitude as well as duration of the ATP-evoked current. $B$, Representative recordings for $\mathrm{P} 2 \mathrm{X}_{2}$ channels expressed in oocytes. Left trace, $100 \mu \mathrm{M}$ ATP-evoked current before and after (right trace) addition of IVM $(10 \mu \mathrm{M})$; IVM causes no change in either the holding current or ATPevoked current in $\mathrm{P} 2 \mathrm{X}_{2}$-expressing cells. $C$, Summary of data from a number of cells $(n>5$ for each) showing that IVM $(10 \mu \mathrm{M})$ potentiates ATP-evoked currents at P2X channels but not at $\mathrm{P} 2 \mathrm{X}_{2}, \mathrm{P} 2 \mathrm{X}_{3}$, and $\mathrm{P} 2 \mathrm{X}_{2} / \mathrm{P} 2 \mathrm{X}_{3}$ channels. $D$, Summary of data from a number of cells $(n>5$ for each) showing that suramin $(30 \mu \mathrm{M})$ can block ATPevoked currents at $\mathrm{P} 2 \mathrm{X}_{2}, \mathrm{P} 2 \mathrm{X}_{3}$, and $\mathrm{P} 2 \mathrm{X}_{2} / \mathrm{P} 2 \mathrm{X}_{3}$ channels but not at $\mathrm{P} 2 \mathrm{X}_{4}$ channels. Subsequent figures show a more pronounced potentiation of $\mathrm{P}_{2} \mathrm{X}_{4}$ channels at lower IVM and/or ATP concentrations. The data are derived from measurements of peak ATP-evoked currents.

\section{RESULTS}

IVM potentiates $\mathrm{P}_{2} \mathrm{X}_{4}$ but not $\mathrm{P} 2 \mathrm{X}_{2}, \mathrm{P} \mathrm{X}_{3}, \mathrm{P}_{2} \mathrm{X}_{2} / \mathrm{P} 2 \mathrm{X}_{3}$, or $\mathrm{P}_{2} \mathrm{X}_{\mathbf{7}}$ channel currents

We expressed homomeric $\mathrm{P}_{2} \mathrm{X}_{4}$ channels in Xenopus oocytes and tested for responses to ATP applications (5-20 sec in duration). Suramin $(30 \mu \mathrm{M})$, which is an antagonist of some types of $\mathrm{P} 2 \mathrm{X}$ ATP receptors, did not inhibit peak currents evoked by $100 \mu \mathrm{M}$ ATP at $\mathrm{P} 2 \mathrm{X}_{4}$ channels $(n=4)$. However, suramin blocked by $>80 \%$ the current evoked by $100 \mu \mathrm{M}$ ATP at both $\mathrm{P}_{2} \mathrm{X}_{2}$ and $\mathrm{P} 2 \mathrm{X}_{3}$ channels (Fig. 1; also see Buell et al., 1996; Seguela et al., 1996). We next tested the action of IVM $(10 \mu \mathrm{M})$ on currents evoked by ATP $(100 \mu \mathrm{M})$ at $\mathrm{P} 2 \mathrm{X}_{2}, \mathrm{P} 2 \mathrm{X}_{3}, \mathrm{P} 2 \mathrm{X}_{2} / \mathrm{P} 2 \mathrm{X}_{3}, \mathrm{P} 2 \mathrm{X}_{4}$, and $\mathrm{P} 2 \mathrm{X}_{7}$ channels. In cells expressing $\mathrm{P} 2 \mathrm{X}_{2}, \mathrm{P} 2 \mathrm{X}_{3}$, or $\mathrm{P} 2 \mathrm{X}_{2} / \mathrm{P} 2 \mathrm{X}_{3}$ channels, IVM produced no significant effect on ATP-evoked currents (Fig. 1); however, in $\mathrm{P}_{2} \mathrm{X}_{4}$-expressing cells, IVM increased the peak ATP-evoked current significantly in all cells tested (by 50-300\% depending on the concentration and incubation time; see below). ATP-evoked currents at $\mathrm{P}_{2} \mathrm{X}_{7}$ channels expressed in oocytes have two phases (Nuttle and Dubyak, 1994; Khakh et al., 1999), and we tested whether IVM could affect either phase of these currents evoked by ATP at $\mathrm{P}_{2} \mathrm{X}_{7}$ channels. Neither phase of the $100 \mu \mathrm{M}$ ATP-evoked current at $\mathrm{P}_{2} \mathrm{X}_{7}$ channels was potentiated by IVM $(10 \mu \mathrm{M})$; the initial current and secondary current peaks were $-512 \pm 76$ and $-7490 \pm 538 \mathrm{nA}$ for ATP alone and $-371 \pm 108$ and $-5257 \pm 945 \mathrm{nA}$ for ATP plus IVM, respectively $(n=3$; unpaired Student's $t$ test, $p>0.05$ ). Homomeric $\mathrm{P}_{2} \mathrm{X}_{1}$ and $\mathrm{P}_{2} \mathrm{X}_{5}$ channel assemblies were not tested for IVM sensitivity.

\section{Functional consequences of $\mathrm{P}^{2} \mathrm{X}_{4}$ channel allosteric modulation}

IVM $(3 \mu \mathrm{M})$ produced a maximal potentiation of ATP-evoked currents at $\mathrm{P} 2 \mathrm{X}_{4}$ channels within $30 \mathrm{sec}$ of application with a time constant $\left(\tau_{\text {on }}\right)$ of $14 \mathrm{sec}$ (Fig. $2 A$; the apparent bimolecular rate constant for association was $2.2 \times 10^{4} \mathrm{M} / \mathrm{sec}$ ). The potentiation by IVM was fully reversible within $10 \mathrm{~min}$ of washing with a time constant $\left(\tau_{\text {off }}\right)$ of $165 \mathrm{sec}$. The data presented in Figure 2 show that the action (and reversal) of IVM is use-independent, suggesting that permeation through open $\mathrm{P} 2 \mathrm{X}$ channels is not required. The action of IVM depends on concentration, with an apparent half-maximal effect $\left(\mathrm{EC}_{50}\right)$ at $\sim 257 \mathrm{nM}$ (for currents evoked by $3 \mu \mathrm{M}$ ATP), which is in good agreement with a $k_{\mathrm{d}}$ of $278 \mathrm{~nm}$ determined from kinetic experiments shown in Figure 2, $A$ and $B$ (see Data analysis). However, the IVM concentrationeffect relationship did not reach a well defined plateau at high concentration (Fig. $2 C$ ), vitiating a systematic description in terms of the Hill function or other dose-response formulations. With IVM at concentrations $\geq 10 \mu \mathrm{M}$ we observed a downward phase of the concentration-effect relationship, and this may represent increased desensitization of $\mathrm{P}_{2} \mathrm{X}_{4}$ channels during ATP application. Importantly, the augmentation by IVM is not attributable to DMSO, because DMSO caused no marked change in the ATPevoked current when it was added to the buffer at $0.1 \%$ (control current evoked by ATP was $-181 \pm 54 \mathrm{nA}$, whereas in the presence of DMSO it was $-167 \pm 91 \mathrm{nA}$ ), but $1 \mu \mathrm{M}$ IVM solutions also contained $0.1 \%$ DMSO and produced a large increase in ATP-evoked current (Fig. 2C).

In control cells $\mathrm{P} 2 \mathrm{X}_{4}$ channels responded to ATP with an $\mathrm{EC}_{50}$ of $3 \mu \mathrm{M}$ (Khakh et al., 1999), with a maximal current of $\sim 2 \mu \mathrm{A}$. However, in oocytes pretreated with $3 \mu \mathrm{M}$ IVM for 2 min before each application of $\mathrm{ATP}$, the $\mathrm{EC}_{50}$ was $0.3 \mu \mathrm{M}$, and the maximal current increased to $\sim 4 \mu \mathrm{A}$ (Fig. $2 D$ ). This profile of action is similar to the effect of IVM on $\alpha 7$ nicotinic channels (Krause et al., 1998) and indicates an allosteric action on $\mathrm{P}_{2} \mathrm{X}_{4}$ channels.

We tested for voltage dependence for the action of IVM, as 
Figure 2. Properties of the IVM potentiation of $\mathrm{P} 2 \mathrm{X}_{4}$ channel currents. $A$, Time course of potentiation by IVM. IVM was added at $t=0$, just after the first puff of ATP (3 $\mu \mathrm{M})$. Potentiation by IVM occurs within $15 \mathrm{sec}$ (time of the second ATP pulse) and is maximal by $30 \mathrm{sec} . B$, The oocyte was exposed once to ATP $(3 \mu \mathrm{M})$ in the absence of IVM $(t=-5 \mathrm{~min})$. Fifteen seconds later, IVM was applied for 5 min. At $t=0$, a second ATP application evoked a greater than fourfold larger ATP response. Thus the ATP-evoked current is potentiated in the absence of ATP, showing that IVM action is use-independent. After washout of IVM, the ATP-evoked current returns to baseline levels within 10-20 min. For $A$ and $B$ the period of IVM application is shown by the horizontal bar, and the bold line is an exponential fit to the data. $C$, Concentration dependence of IVM action, tested with pulses of $1 \mu \mathrm{M}$ ATP. IVM causes significant potentiation at concentrations $\geq 0.1 \mu \mathrm{M}$. The superimposed heavy line represents a fitted curve (Hill equation) with an $\mathrm{EC}_{50}$ of $257 \mathrm{~nm}$ and a Hill coefficient of 1 ; note, however, that the IVM potentiation decreases at 10 $\mu$ M. D. Concentration-effect relationship for ATP in the absence (O) and presence (O) of $3 \mu \mathrm{M}$ IVM. IVM both increases the maximal current and decreases the $\mathrm{EC}_{50}$ for ATP. E, Leak-subtracted current-voltage relationships for the ATP-evoked current in the absence $(\bullet)$ and presence (O) of $3 \mu \mathrm{M}$ IVM; note that there is no shift in the reversal potential. $F$, Data from experiments like that shown in $D$. The ratio of the IVM potentiated current to that of the ATP-evoked current alone is plotted versus the membrane voltage. IVM can potentiate the ATP-evoked current at all membrane voltages tested; in addition, the potentiation is slightly greater at positive voltages. For this figure the data are plotted as mean \pm SEM.
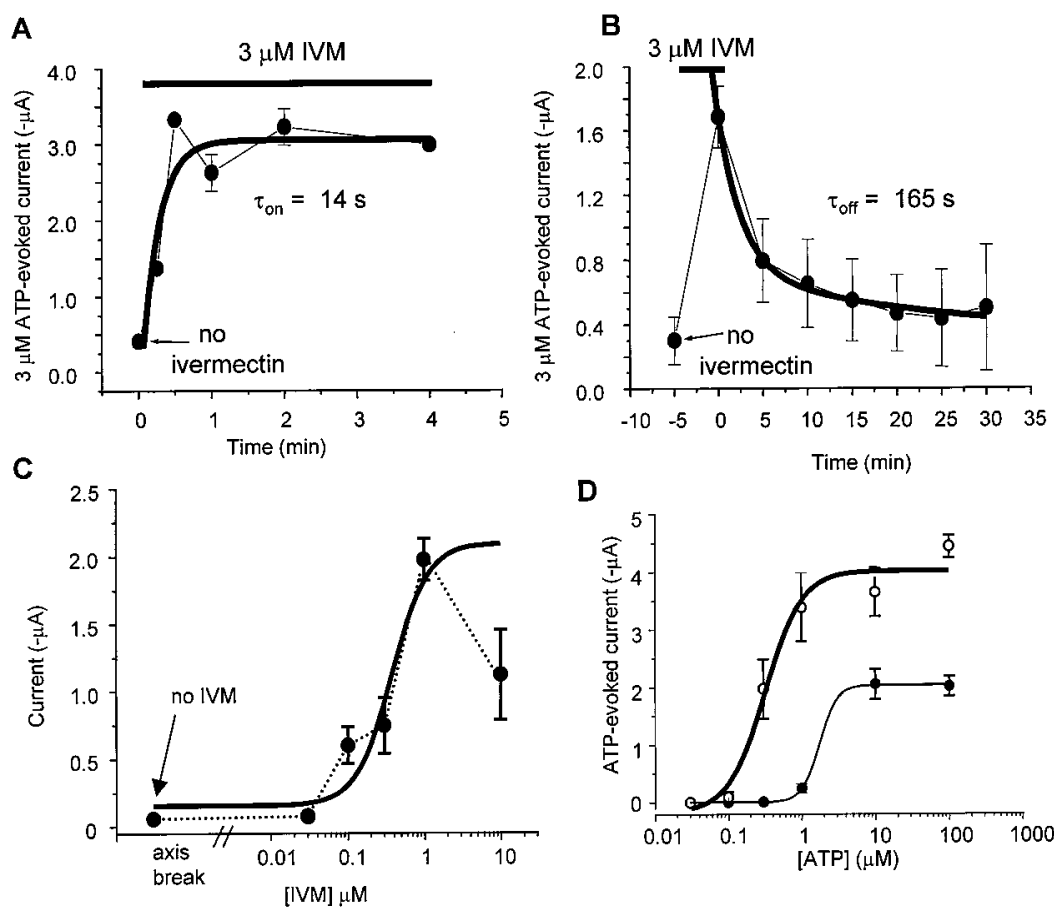

D
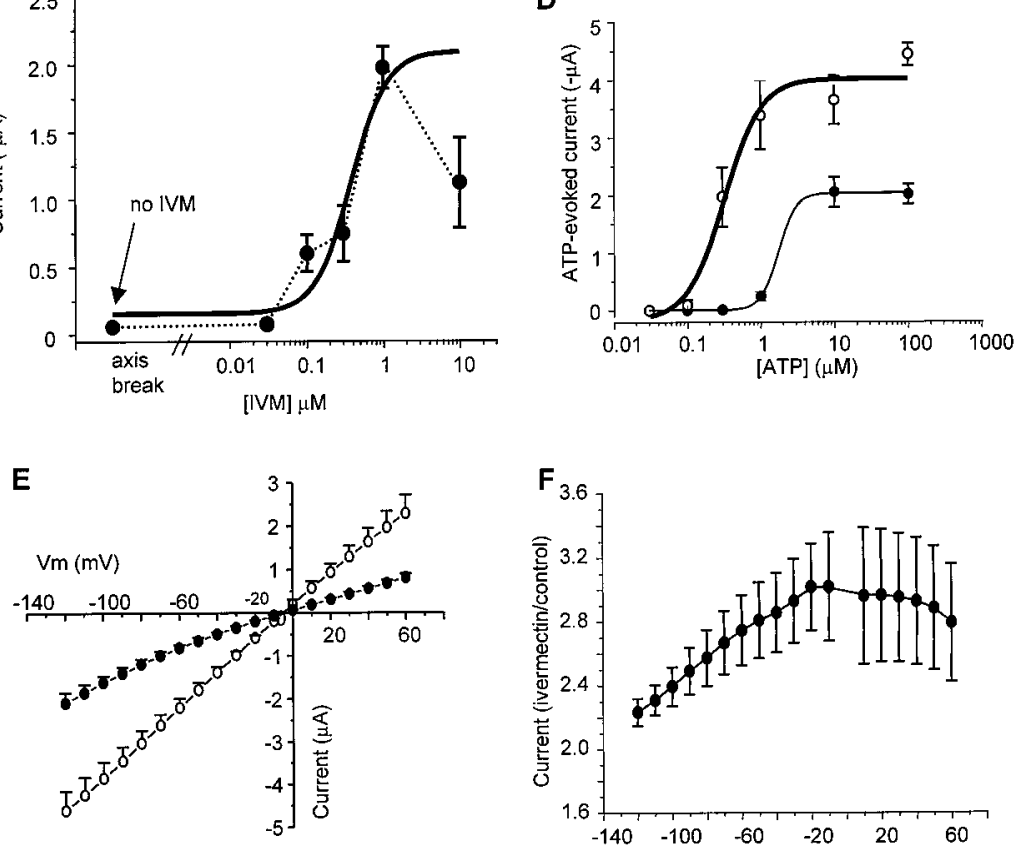

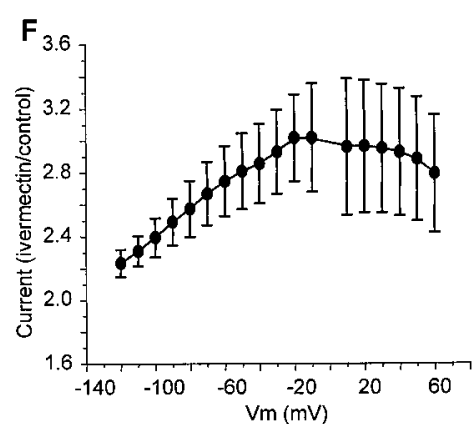

would be expected if its site of action were inside the pore. The data show that IVM does not cause any shift in the reversal potential of the ATP-evoked current-voltage relationship and that the IVM potentiation occurs at all membrane voltages $(-120$ to $+60 \mathrm{mV}$ with $3 \mu \mathrm{M}$ IVM and 10 or $100 \mu \mathrm{M}$ ATP; Fig. $2 E$ ). Figure $2 F$ shows these data plotted as a ratio of the IVMpotentiated current to the ATP-evoked current alone versus membrane potential. Although the potentiating effect of IVM clearly occurs at all membrane potentials, it does in addition display weak voltage dependence; the effect is smaller at voltages negative to $-60 \mathrm{mV}$ than at voltages more positive than this.

In addition to increasing the peak current mediated by $\mathrm{P} 2 \mathrm{X}_{4}$ channels, IVM also increased the decay time of the ATP-evoked currents at $\mathrm{P} 2 \mathrm{X}_{4}$ channels by $\sim 30$-fold (Fig. $3 A, C$ ). This suggests that IVM increases the affinity of $\mathrm{P}_{2} \mathrm{X}_{4}$ channels for ATP, and that once bound in the presence of IVM, ATP dissociates slowly from the channel. Alternatively $\mathrm{P}_{2} \mathrm{X}_{4}$ channels may be less likely to enter a desensitized state after IVM application. We also determined the effect of IVM on total charge transfer during ATP-evoked currents; this was increased markedly (36 \pm 8 -fold) by IVM from $4.1 \pm 0.8 \mu \mathrm{C}$ in control to $149 \pm 37 \mu \mathrm{C}$ with IVM. There was no change in membrane capacitance (Fig. $3 D$ ) during IVM application, suggesting that the effect of IVM on the peak ATP-evoked currents is probably not attributable to the insertion of vesicles containing a new population of $\mathrm{P} 2 \mathrm{X}_{4}$ channels. Instead the increase in peak ATP-evoked current, slowing of deactivation, and decrease in $\mathrm{EC}_{50}$ for ATP are most readily explained by modulation of the existing population of $\mathrm{P} 2 \mathrm{X}_{4}$ channels.

The ATP analog $\alpha, \beta$-methylene-ATP is a weak agonist at $\mathrm{P}_{2} \mathrm{X}_{4}$ channels, producing $<10 \%$ of the current evoked by ATP (Fig. $4 A$ ) even at high concentrations (Buell et al., 1996; Seguela et al., 1996; Michel et al., 1997; Le et al., 1998a), indicating that it is a low-efficacy agonist (Colquhoun, 1998). An allosteric effector acts independently of the agonist binding site and would therefore be expected to affect both ATP and $\alpha, \beta$-methylene-ATP responses. Indeed, IVM $(3 \mu \mathrm{M})$ increased the inward current evoked by 30 $\mu \mathrm{M} \alpha, \beta$-methylene-ATP significantly from $-15 \pm 6 \mathrm{nA}$ with $\alpha, \beta$-methylene-ATP alone to $-357 \pm 147 \mathrm{nA}$ for $\alpha, \beta$-methyleneATP plus IVM $(n=5)$; on the same occasions as these experiments were performed, IVM $(3 \mu \mathrm{M})$ increased the current evoked by ATP $(30 \mu \mathrm{M})$ from $-273 \pm 75$ to $-857 \pm 284 \mathrm{nA}(n=5)$. These data prompted us to investigate the action of IVM $(3 \mu \mathrm{M})$ on the concentration-effect relationship of $\alpha, \beta$-methylene-ATP. IV M converted $\alpha, \beta$-methylene-ATP from a weak agonist with an $\mathrm{EC}_{50}$ of $>300 \mu \mathrm{M}$ to a more potent agonist, one with an $\mathrm{EC}_{50}$ of $19 \mu \mathrm{M}$ (Fig. 4A), and thus provides direct evidence for allosteric modulation of $\mathrm{P}_{2} \mathrm{X}_{4}$ channels by IVM. 
A
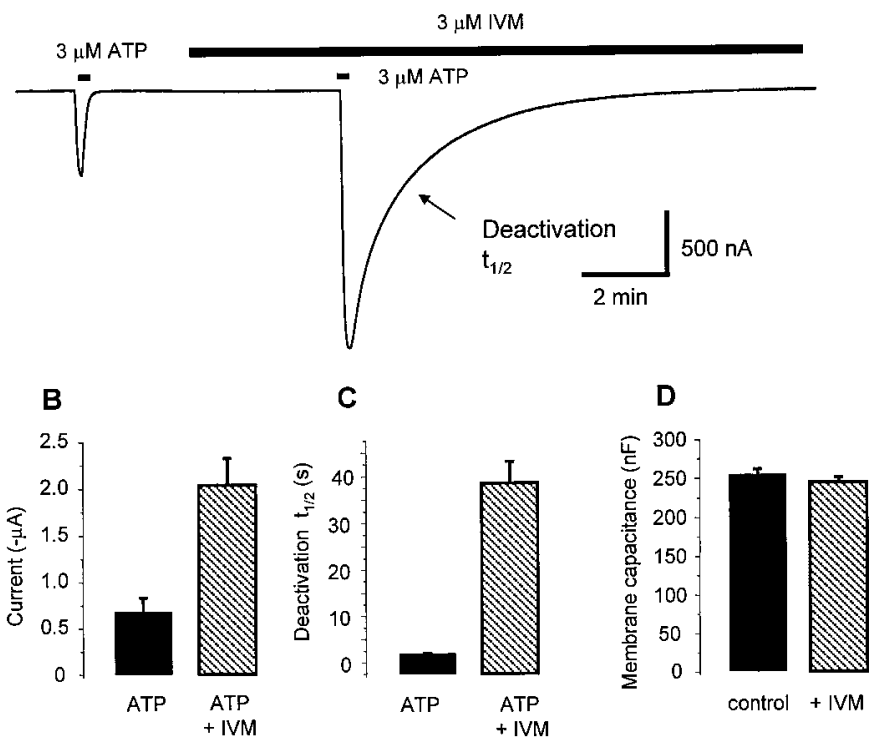

Figure 3. IVM affects $\mathrm{P} 2 \mathrm{X}_{4}$ deactivation kinetics but neither basal current nor membrane capacitance. $A$, Representative recording showing that IVM produces a large increase in $\mathrm{P} 2 \mathrm{X}_{4}$ channel current evoked by 3 $\mu \mathrm{M}$ ATP, although IV M produces no change in the holding current. $B-D$, Bar graphs showing summary of ATP-evoked current properties from cells recorded in the experiment shown in $A$. $B$, peak response; $\mathrm{C}$, deactivation half-time; $D$, cell capacitance.

\section{Channels formed by co-expression of $\mathrm{P}^{2} \mathrm{X}_{4}$ and P2X $_{6}$ channels}

We found no evidence for ATP-evoked or $\alpha, \beta$-methylene-ATPevoked currents at homomeric $\mathrm{P} 2 \mathrm{X}_{6}$ channels expressed in oocytes (with or without $3 \mu \mathrm{M} \mathrm{IVM}$ ), and this indicates that $\mathrm{P} 2 \mathrm{X}_{6}$ channels are nonfunctional in oocytes (also see Le et al., 1998a). However, in agreement with previous data when $\mathrm{P}_{2} \mathrm{X}_{4}$ and $\mathrm{P} 2 \mathrm{X}_{6}$ channels were co-expressed, we observed $\alpha, \beta$-methylene-ATPevoked currents with a threshold concentration of $10 \mu \mathrm{M}$, and $\mathrm{EC}_{50}$ of $25 \mu \mathrm{M}$ (Table 1). The heteromeric $\mathrm{P}_{2} \mathrm{X}_{4} / \mathrm{P} 2 \mathrm{X}_{6}$ channel displays a phenotype distinct from either $\mathrm{P}_{2} \mathrm{X}_{4}$ or $\mathrm{P} 2 \mathrm{X}_{6}$ channels alone (Le et al., 1998a); in particular, the threshold concentration for $\alpha, \beta$-methylene-ATP at $\mathrm{P} 2 \mathrm{X}_{4}$ channels was $300 \mu \mathrm{M}$ (Fig. $4 A$, Table 1), indicating that the heteromer formed by co-expression of $\mathrm{P}_{2} \mathrm{X}_{4}$ and $\mathrm{P} 2 \mathrm{X}_{6}$ channels has a higher sensitivity to $\alpha, \beta$ methylene-ATP than does homomultimeric $\mathrm{P} 2 \mathrm{X}_{4}$ alone (Le et al., 1998a). We next tested the action of $3 \mu \mathrm{M} \mathrm{IVM}$ in cells expressing $\mathrm{P} 2 \mathrm{X}_{4} / \mathrm{P} 2 \mathrm{X}_{6}$ channels. In the most important observation, IVM decreased the $\alpha, \beta$-methylene-ATP threshold concentration from 10 to $3 \mu \mathrm{M}$ (Fig. $4 B$, asterisk). Because homomeric $\mathrm{P} 2 \mathrm{X}_{4}$ channels do not respond detectably to $3 \mu \mathrm{M} \alpha, \beta$-methylene-ATP, this observation suggests-but does not prove - that IVM also potentiates a distinct receptor species, presumably the $\mathrm{P} 2 \mathrm{X}_{4} / \mathrm{P} 2 \mathrm{X}_{6}$ receptor.

In oocytes co-injected with $\mathrm{P} 2 \mathrm{X}_{4}$ and $\mathrm{P} 2 \mathrm{X}_{6}$ mRNA, IVM also potentiated agonist-evoked currents at $\alpha, \beta$-methylene-ATP concentrations $>10 \mu \mathrm{M}$ and decreased the $\mathrm{EC}_{50}$ from 25 to $16 \mu \mathrm{M}$ (Table 1). These IVM actions could arise via effects at homomeric $\mathrm{P} 2 \mathrm{X}_{4}$ channels that may also be present in the oocytes (Fig. 4 , Table 1) and are therefore less convincing than the differences in threshold $\alpha, \beta$-methylene-ATP concentration.

\section{IVM modulates only the $I_{\mathbf{1}}$ states of $\mathrm{P}^{2} \mathrm{X}_{\mathbf{4}}$ channels}

Recent data show that $\mathrm{P} 2 \mathrm{X}_{4}$ channels display biphasic currents during prolonged ATP applications in $\mathrm{Na}^{+}$solutions (Fig. $5, I_{1}$, $\left.I_{2}\right)$. The second phase is attributable to a history-dependent increase in permeability (Khakh et al., 1999; Virginio et al., 1999). We tested whether IVM modulates both $I_{1}$ and $I_{2}$, and found that only the initial ATP-evoked current $\left(I_{1}, 10-20 \mathrm{sec}\right.$ ATP applications), is potentiated (Fig. 5). This provides further evidence that $I_{2}$ occurs independently of the magnitude of inward current during $I_{1}$ (Khakh et al., 1999). However, it remained possible that the potentiated $I_{1}$ current was in fact caused by a recruitment of some channels from the $I_{2}$ state, such that they now opened with brief ATP applications. To address this directly, we determined $\mathrm{NMDG}^{+}$permeability ratios for the control and IVM-potentiated currents, because $\mathrm{NMDG}^{+}$is substantially permeable during the $I_{2}$ current, and is only weakly permeable during $I_{1}$. The reversal potential for ATP-evoked current alone $\left(I_{1}\right)$ was $-50.5 \mathrm{mV}$, whereas that for the IVM-potentiated current was $-47.9 \mathrm{mV}$ (see Fig. $5 ; n=5$ ). In comparison, the reversal potential for $I_{2}$ is typically $-30 \mathrm{mV}$ (Khakh et al., 1999). The $\mathrm{pNMDG}^{+} / \mathrm{pNa}^{+}$ratios for control ATP-evoked currents and the IVM-potentiated currents were identical (Fig. 5D). This indicates that control currents and IVM-enhanced currents have equally low permeability to $\mathrm{NMDG}^{+}$. Therefore, the previously reported low-selectivity $I_{2}$ state (Khakh et al., 1999) does not contribute detectably to the IVM-potentiated current; IVM potentiates only $I_{1}$. The mechanism(s) of ion selectivity changes are not fully understood but likely involve structural rearrangements in the permeation pathway (Khakh et al., 1999; Virginio et al., 1999). We presume that IVM binds less strongly to the $I_{2}$ state than to the $I_{1}$ state or does not enhance the conformational change that leads to opening of this state. This extends previous findings demonstrating that the distinct selectivity states of $\mathrm{P} 2 \mathrm{X}_{7}$ channels can be probed differentially by blockers (for review, see Ralevic and Burnstock, 1998).

\section{Allosteric modulation in a clonal mammalian cell line}

To circumvent desensitization we applied ATP every 2 min to HEK 293 cells transfected with $\mathrm{P}_{2} \mathrm{X}_{4}$ channels. After three doses of ATP we applied IVM ( $3 \mu \mathrm{M})$ for 4 min and repeated the ATP applications. These experiments show that IVM can augment ATP-evoked currents in $\mathrm{P}_{2} \mathrm{X}_{4}$-transfected mammalian cells. The peak effect and kinetics resemble those observed for IVM action in oocytes, demonstrating that the effect of IVM on $\mathrm{P} 2 \mathrm{X}_{4}$ channels is independent of the host cell (Fig. 6; top graph is from a single HEK 293 cell; bottom graph is an average from four such cells).

\section{Brainstem and hippocampal neurons expressing P2X channels}

The brainstem MNV contains proprioceptive neurons that express transcripts for $\mathrm{P}_{2} \mathrm{X}_{4}, \mathrm{P} 2 \mathrm{X}_{5}$, and $\mathrm{P} 2 \mathrm{X}_{6}$ (Collo et al., 1996); $\mathrm{P} 2 \mathrm{X}$ responses are recorded on MNV neuron somata and central terminals (Cook et al., 1997; Khakh et al., 1997; Khakh and Henderson, 1998a). In agreement with these studies, ATP (50 $\mu \mathrm{M})$ puffed directly onto the somata evoked inward currents in these neurons, but IVM $(5 \mu \mathrm{M})$ did not affect these ATP-evoked currents ( $<5 \%$ change; $n=3$; Fig. 7$)$. These data provide further evidence that the P2X channels in MNV neurons do not comprise homomeric $\mathrm{P}_{2} \mathrm{X}_{4}$ channels and thus extend previous findings using electrophysiological approaches (Cook et al., 1997; Khakh et al., 1997). 
Figure 4. Effect of $\alpha, \beta$-methylene-ATP on homomeric $\mathrm{P} 2 \mathrm{X}_{4}$ and heteromeric $\mathrm{P} 2 \mathrm{X}_{4} /$ $\mathrm{P} 2 \mathrm{X}_{6}$ channels. $A, \mathrm{P} 2 \mathrm{X}_{4}$ channels: concentration-effect curves for $\alpha, \beta$-methylene-ATP in the absence and presence of $3 \mu \mathrm{M}$ IVM. Right graphs, Same data on an expanded current scale. $B$, Co-expression of $\mathrm{P} 2 \mathrm{X}_{4} / \mathrm{P} 2 \mathrm{X}_{6}$ channels: concentration-effect curves for $\alpha, \beta$ methylene-ATP in the absence and presence of $3 \mu \mathrm{M}$ IVM. Right graphs, Same data on an expanded current scale. The asterisks indicate the threshold concentration for $\alpha, \beta$-methyleneATP (see Table 1).
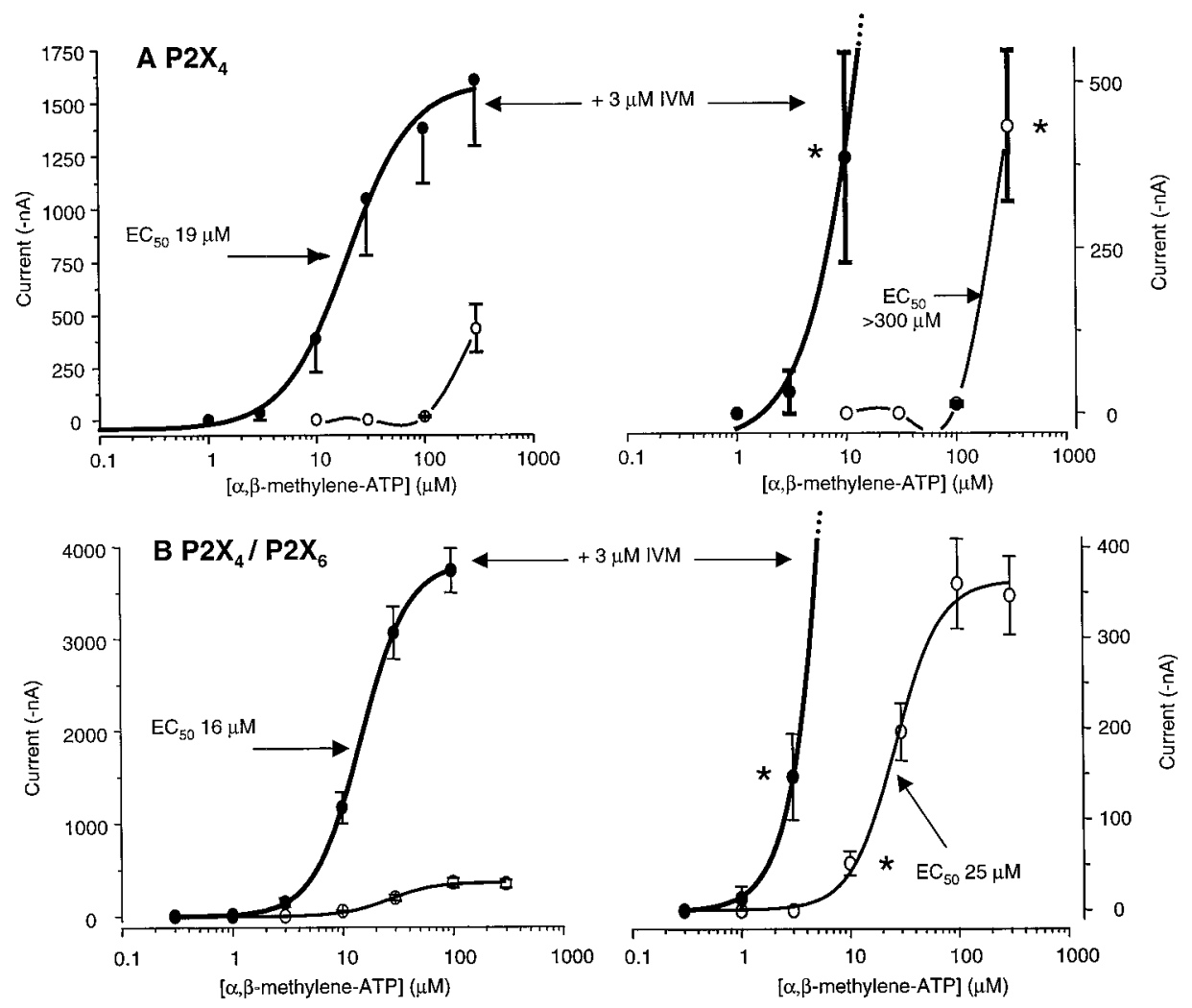

Table 1. Properties of $\alpha, \beta$-methylene-ATP concentration-effect curves with and without IVM on P2X $_{4}$ receptors alone or when expressed in combination with $P 2 X_{6}$ receptors

\begin{tabular}{llccccc} 
Receptor & $\alpha, \beta$-Methylene-ATP & Threshold $(\mu \mathrm{M})$ & $\mathrm{EC}_{50}(\mu \mathrm{M})$ & Hill slope & $I_{\max }(-\mathrm{nA})^{a}$ & $n$ \\
\hline P2X $_{4}$ & Control & 300 & $>300$ & $b$ & $433 \pm 113$ & 7 \\
& + IVM $(3 \mu \mathrm{M})$ & 10 & $19.8 \pm 3.7$ & $2.0 \pm 0.2$ & $1608 \pm 311$ & 6 \\
$\mathrm{P}^{2} \mathrm{X}_{4} / \mathrm{P} 2 \mathrm{X}_{6}$ & Control & 10 & $25.1 \pm 2.7^{*}$ & $1.8 \pm 0.3$ & $360 \pm 50$ & 8 \\
& + IVM $(3 \mu \mathrm{M})$ & 3 & $15.6 \pm 1.4^{*}$ & $2.2 \pm 0.1$ & $3739 \pm 244$ & 9
\end{tabular}

${ }^{a} I_{\max }$ is the largest current on the concentration-effect curve to $\alpha, \beta$-methylene-ATP (100 or $\left.300 \mu \mathrm{M}\right)$.

${ }^{b}$ The Hill slope was not possible to determine.

*Statistical difference (at $p<0.05)$ between these two $\mathrm{EC}_{50}$ values $(p=0.005$; unpaired Student's $t$ test; also see Figure 4 for graphs).

Recent studies in CA1 pyramidal neurons have demonstrated rapid ATP-evoked currents and fast ATP synaptic transmission (Pankratov et al., 1998; Proctor and Dunwiddie, 1998), but the identity of the P2X channels in CA1 neurons is uncertain, in part because they express many mRNA species, including $\mathrm{P}_{2} \mathrm{X}_{4}$ (Collo et al., 1996). If IVM could modulate the ATP-evoked currents in these neurons, this might indicate the presence of homomeric $\mathrm{P}_{2} \mathrm{X}_{4}$ or possibly $\mathrm{P} 2 \mathrm{X}_{4}$-containing channels. However, when responses to locally applied ATP were recorded from identified hippocampal CA1 pyramidal neurons, ATP-evoked currents in the majority of neurons were unaffected by IVM (13 of 13 neurons responded to ATP, but 10 of these 13 did not respond to IVM; Fig. 7). A potential concern in these experiments was the possibility that IVM does not penetrate brain slices effectively. However, in parallel experiments we found that $2 \mu \mathrm{M} \mathrm{IVM}$ markedly potentiated fast $\mathrm{GABA}_{\mathrm{A}}$ channel currents evoked by puffing GABA on to CA1 neurons; the effect of IVM was both rapid and reversible $(n=3)$, suggesting that IVM does in fact penetrate brain slices. In three neurons we observed larger ATPevoked currents in the presence of IVM than in control. However when the data from all 13 cells were averaged, the increase was not significant (174 $\pm 85 \%$ of control). To gain further insight as to the nature of the $\mathrm{P} 2 \mathrm{X}$ channels expressed on CA1 neurons and to allow comparison with other neurons, we next tested the action of $\alpha, \beta$-methylene-ATP. $\alpha, \beta$-Methylene-ATP is a weak agonist at homomeric $\mathrm{P} 2 \mathrm{X}_{4}$ channels (Fig. $4 A$ ) but is a potent agonist at known CNS heteromeric channels (Le et al., 1998a; Torres et al., 1998); it is known to activate P2X channels that are endogenously expressed in neurons, some of which are most likely heteromeric assemblies [e.g., sensory neurons (Chen et al., 1995; Khakh et al., 1995a; Lewis et al., 1995; Cook et al., 1997), medial habenula neurons (Edwards et al., 1992), and locus coeruleus neurons (Nieber et al., 1997)]. When we puffed $\alpha, \beta$-methylene-ATP (50 $\mu \mathrm{M})$ onto CA1 neurons we observed large fast inward currents ( $-98 \pm 19 \mathrm{pA}$; six of six neurons). This observation, in combination with the lack of effect of IVM on most cells, provides the first functional evidence to indicate that homomeric $\mathrm{P}_{2} \mathrm{X}_{4}$ channels are not expressed in the majority of adult hippocampal CA1 region neurons, despite the fact that in situ hybridization studies show that their transcripts are abundant here (Buell et al., 1996; 


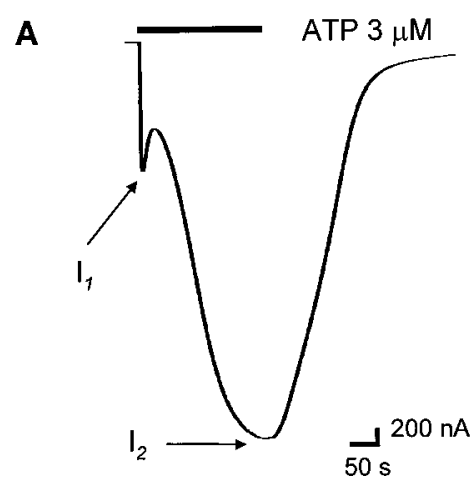

B

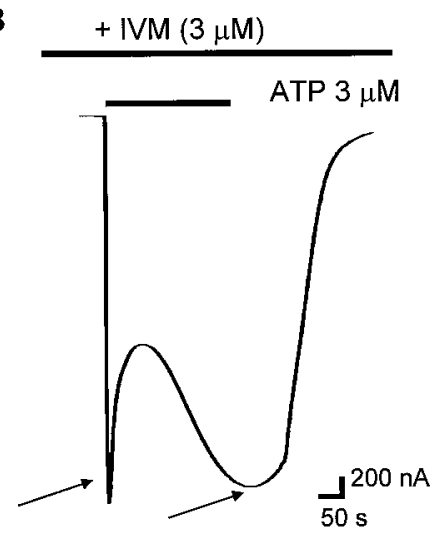

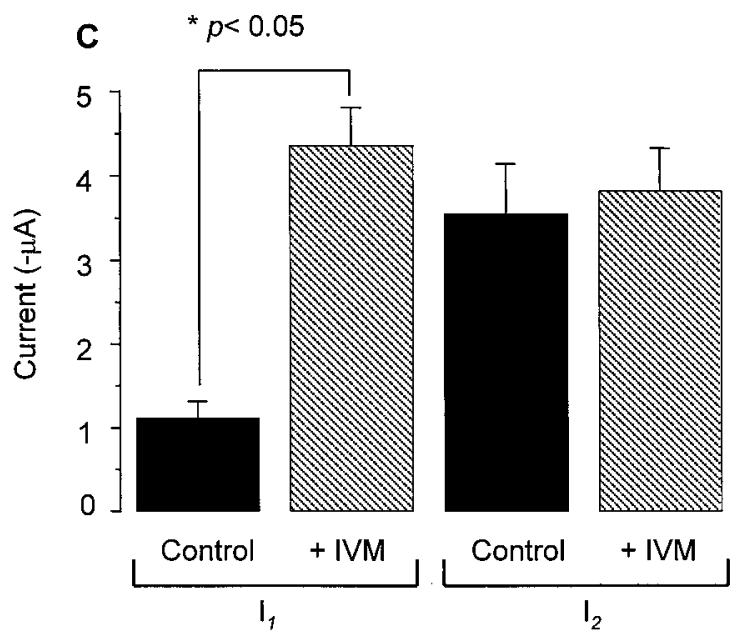

D $\mathrm{E}_{\mathrm{rev}}(\mathrm{mV})$ $\mathrm{Na}^{+} \mathrm{NMDG}^{+} p \mathrm{NMDG}^{+} / p \mathrm{Na}^{+}$

$\mathrm{I}_{1}$

$\begin{array}{ll}0 & -51 \pm 2\end{array}$

$0.15 \pm 0.02\rceil p>0.05$

Figure 5. IVM potentiates the high-selectivity $\left(I_{1}\right)$ but not the low-selectivity $\left(I_{2}\right)$ state of the P2X ${ }_{4}$ channel. $A$, Representative $3 \mu \mathrm{M}$ ATP-evoked current from an oocyte expressing $\mathrm{P} 2 \mathrm{X}_{4}$ channels; the solid bar indicates the period of ATP application. $B$, Representative recording of a $3 \mu \mathrm{M}$ ATP-evoked current during exposure to IVM $(3 \mu \mathrm{M})$. $C$, Bar graph summarizing data from experiments such as those illustrated in $A$ and $B$ from seven cells; only $I_{1}$ is potentiated. $D$, Table showing reversal potentials for control and IVM-potentiated $I_{1}$ in both Na ${ }^{+}$and NMDG ${ }^{+}$solutions, as well as the ratio of $\mathrm{NMDG}^{+}$to $\mathrm{Na}^{+}$permeability $(n=5)$. The $\mathrm{NMDG}^{+}$reversal potential for $I_{2}$ is typically $-30 \mathrm{mV}$ (Khakh et al., 1999).

Collo et al., 1996); overall this supports and extends previous findings using immunocytochemistry (Le et al., 1998a).

Conclusions about the lack of effect of IVM against ATPevoked currents in brain slice neurons would be invalid if for unknown reasons IVM does not modulate $\mathrm{P} 2 \mathrm{X}_{4}$ channels when expressed in neurons. To address this directly we transfected embryonic hippocampal neurons with $\mathrm{P}_{2} \mathrm{X}_{4}$ and used EGFP as a transfection reporter. Untransfected neurons show no ATPevoked responses (Fig. 8C,D, top; 0.1-1 mM ATP), consistent with in situ hybridization studies showing minimal levels of $\mathrm{P}_{2} \mathrm{X}_{4}$ transcripts in the embryonic hippocampus (Buell et al., 1996). We used the presence of EGFP fluorescence (24-48 hr after transfection) to identify transfected neurons; such neurons responded with large ATP-evoked inward currents or membrane depolarizations (Fig. $8 C, D)$. We next tested the action of IVM $(3 \mu \mathrm{M})$ on ATP-evoked currents in transfected hippocampal neurons, and IVM markedly augmented the ATP-evoked currents in all neurons tested (Fig. 8E,F). These experiments provide direct evidence that IVM can modulate $\mathrm{P}_{2} \mathrm{X}_{4}$ channels when expressed in neurons and allow unambiguous interpretation of the data showing little effect of IVM on neurons in hippocampal slices (see above and Fig. 7).

\section{DISCUSSION}

The main finding of the present study is that IVM can augment ATP-evoked currents at homomeric $\mathrm{P}_{2} \mathrm{X}_{4}$ channels, and possibly $\mathrm{P} 2 \mathrm{X}_{4} / \mathrm{P} 2 \mathrm{X}_{6}$ channels, by an allosteric mechanism.

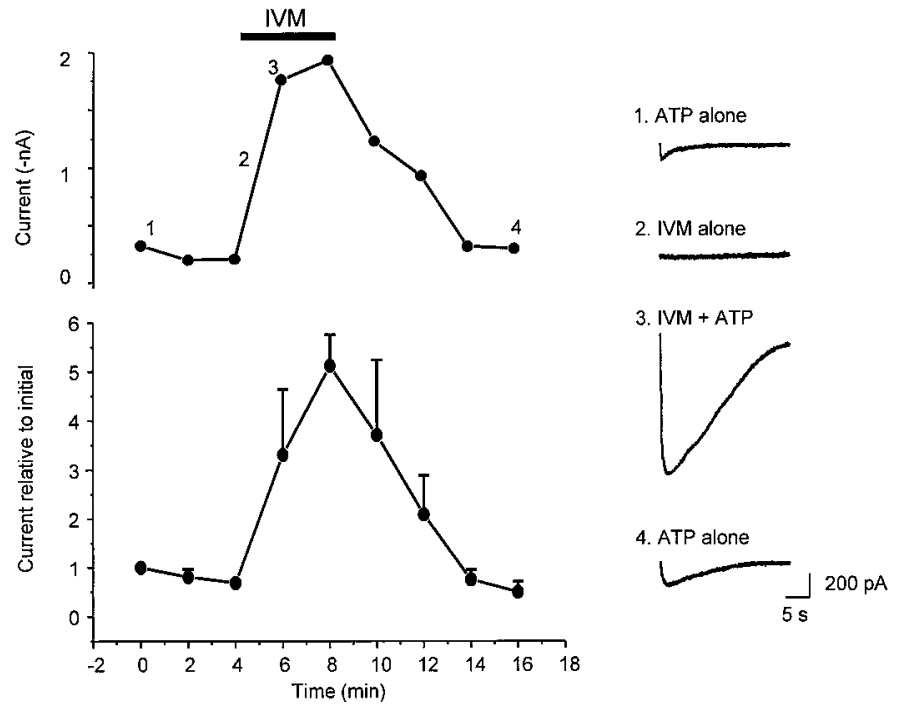

Figure 6. IVM potentiates $\mathrm{P} 2 \mathrm{X}_{4}$ channel currents in a clonal mammalian cell line. Top panel, Amplitudes of ATP $(10 \mu \mathrm{M})$-evoked currents from a single HEK 293 cell; ATP was applied every 2 min and IVM $(3 \mu \mathrm{M})$ was added for the period indicated. The sample traces at the right were elicited from this cell at the time points indicated. Bottom panel, Averaged data from four such cells tested with the same protocol. 


\section{A. MNV neurons}

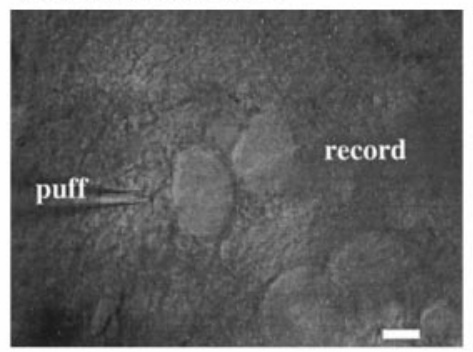

C

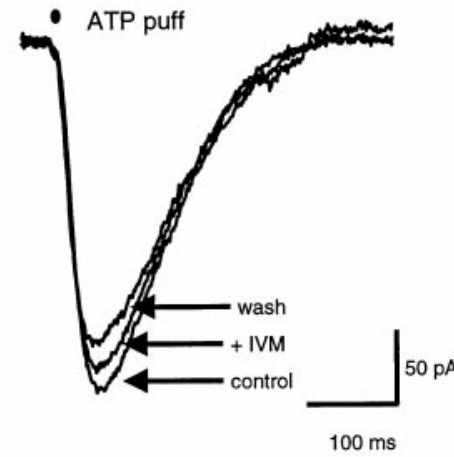

Figure 7. Endogenous $\mathrm{P} 2 \mathrm{X}$ channels in $\mathrm{MNV}$ and hippocampal CA1 neurons. $A$, Bright-field image of a brainstem slice containing the MNV. MNV neurons can be seen as round neurons. Scale bar, $10 \mu \mathrm{m}$. $B$, Image of the CA1 region in a hippocampal slice. CA1 pyramidal neurons can be seen extending a dendrite into the stratum radiatum. Scale bar, $10 \mu \mathrm{m}$. $C$, Representative ATPevoked currents from an MNV neuron. $D$, Representative traces of ATP-evoked currents from a CA1 neuron. In both cases recordings in the presence of 2-5 $\mu \mathrm{M}$ IVM are also shown. The bar graph represents average values for MNV neurons $(n=3)$, whereas the scatter graph shows data for nonresponding CA1 neurons $(\bigcirc)$, the three responding neurons $(\boldsymbol{\square}$; arrows), and the average for all 13 neurons $(\bullet)$.

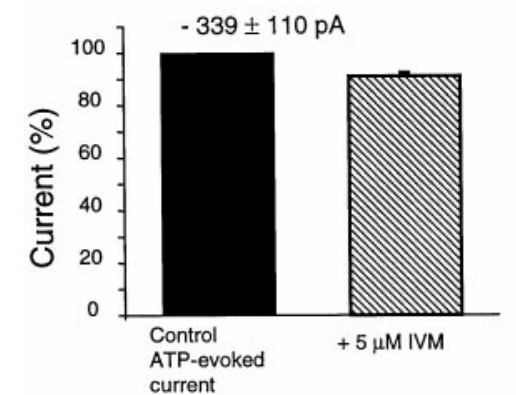

\section{B. CA1 neurons}
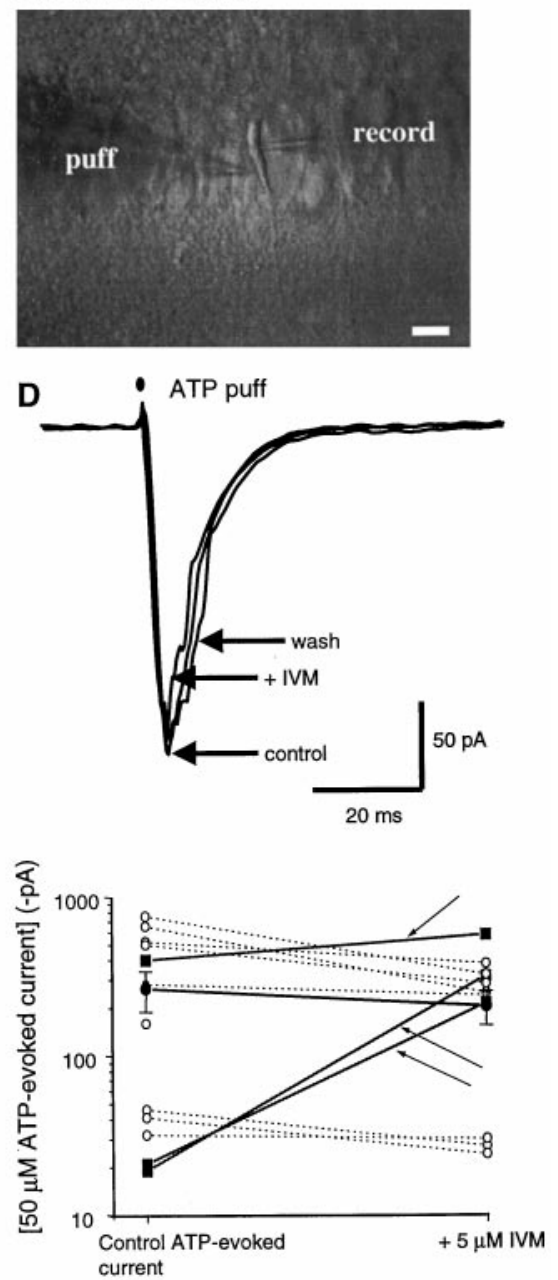

\section{Functional sequelae of $\mathbf{P} 2 \mathbf{X}_{\mathbf{4}}$ channel allosterism}

IVM is an agonist at glutamate-gated chloride channels of invertebrates (Cully et al., 1994) and is a positive allosteric effector of $\mathrm{GABA}_{\mathrm{A}}$ and $\alpha 7$ nicotinic channels (Krusek and Zemkova, 1994; Krause et al., 1998). These ligand-gated channels all belong to the four transmembrane domains per subunit superfamily (Krusek and Zemkova, 1994; Krause et al., 1998). In contrast, the P2X channels are unrelated to these channels both at the level of amino acid sequence and protein topology (North, 1996). At present the binding site for IVM on any ion channel is unknown; sequence comparisons among $\mathrm{P}_{2} \mathrm{X}_{4}$ channels, glutamate-gated chloride channels, or $\alpha_{7}$ nicotinic channels reveal no real clues. Nevertheless, IVM is most likely acting on $\mathrm{P}_{2} \mathrm{X}_{4}$ channels themselves and not on components that are endogenous to oocytes, such as calcium-activated chloride channels, for two reasons. First, the effect of IVM was specific to $\mathrm{P}_{2} \mathrm{X}_{4}$ and possibly $\mathrm{P}_{2} \mathrm{X}_{4} /$ $\mathrm{P} 2 \mathrm{X}_{6}$ channels; $\mathrm{P} 2 \mathrm{X}_{2}, \mathrm{P} 2 \mathrm{X}_{3}, \mathrm{P} 2 \mathrm{X}_{2} / \mathrm{P} 2 \mathrm{X}_{3}$, or $\mathrm{P} 2 \mathrm{X}_{7}$ channels were unaffected, although these channels are also calcium-permeable. The evidence for potentiation of $\mathrm{P} 2 \mathrm{X}_{4} / \mathrm{P} 2 \mathrm{X}_{6}$ channels is not decisive. Second, the kinetics and degree of potentiation for IVM were similar in oocytes, HEK-293 cells, and embryonic hippocampal neurons, clearly demonstrating that the effect of IVM is independent of the host cell in which $\mathrm{P}_{2} \mathrm{X}_{4}$ channels are expressed. The present results demonstrate that IVM specifically increases ATP-evoked currents mediated by $\mathrm{P}_{2} \mathrm{X}_{4}$ channels and suggest that $\mathrm{P} 2 \mathrm{X}_{4}$ channels contain an allosteric binding site for IVM. IVM does not markedly affect ATP-evoked currents mediated by other $\mathrm{P} 2 \mathrm{X}$ subunits expressed in oocytes, such as the $\mathrm{P} 2 \mathrm{X}_{2}$ channels, which are found in the central and peripheral nervous systems (for review, see Ralevic and Burnstock, 1998), $\mathrm{P}_{2} \mathrm{X}_{3}$ channels, which are abundant in pain sensors (Chen et al., 1995; Lewis et al., 1995; Cook et al., 1997), or P2X $\mathrm{X}_{7}$ channels, which are found in immune cells (Nuttle and Dubyak, 1994; Surprenant et al., 1996; Collo et al., 1997). Thus, IVM may be a useful pharmacological tool that can discriminate central $\mathrm{P}_{2} \mathrm{X}_{4}$ from other P2X channels.

Previously, radioligand-binding studies have suggested that ATP binding to $\mathrm{P}_{2} \mathrm{X}_{4}$ channels can be modulated allosterically (Michel et al., 1997). By using IVM we (1) identify a novel chemical structure that specifically probes $\mathrm{P}_{2} \mathrm{X}_{4}$ channels, (2) characterize the effects of this modulation on the properties of $\mathrm{P}_{2} \mathrm{X}_{4}$ channels, and (3) show that $\mathrm{P}_{2} \mathrm{X}_{4}$ channel modulation by IVM is by an allosteric mechanism. In agreement with published functional studies that show suramin to be ineffective at $\mathrm{P} 2 \mathrm{X}_{4}$ channels (Buell et al., 1996; Seguela et al., 1996; Soto et al., 1996), we find no evidence to show that suramin can modulate $\mathrm{P}_{2} \mathrm{X}_{4}$ channel currents.

An allosteric action of IVM on $\mathrm{P}_{2} \mathrm{X}_{4}$ is supported by the observations that IVM rarely produced a change in the holding current by itself but potentiated the current evoked by ATP and 

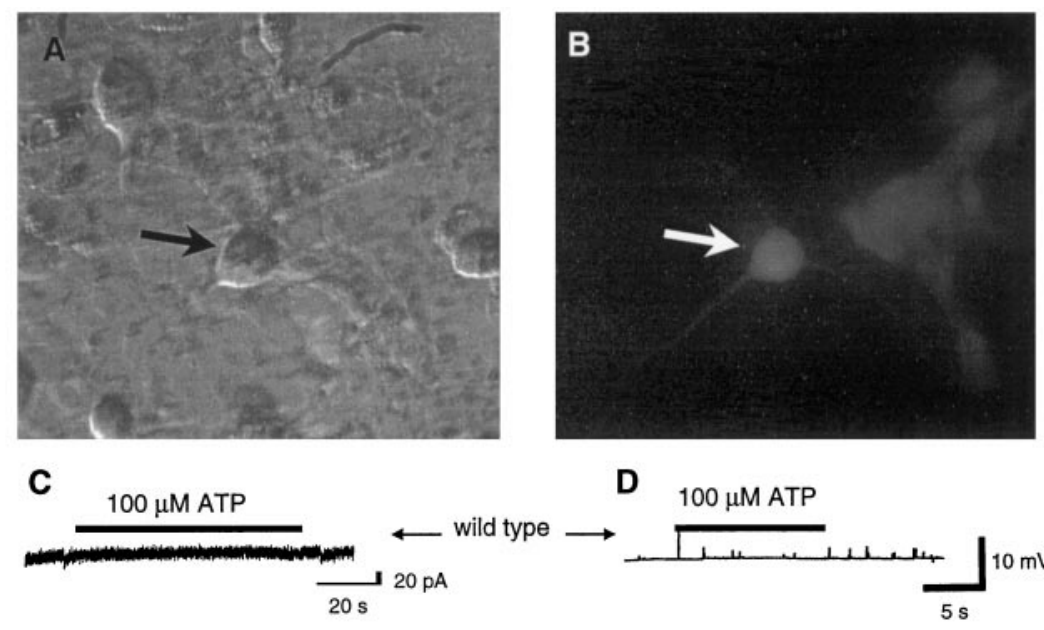

D $100 \mu \mathrm{M}$ ATP
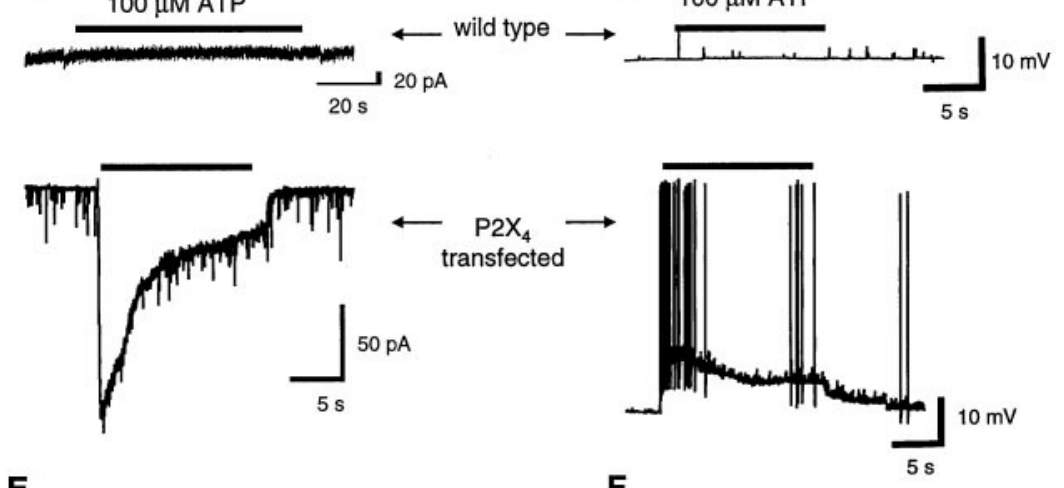

E

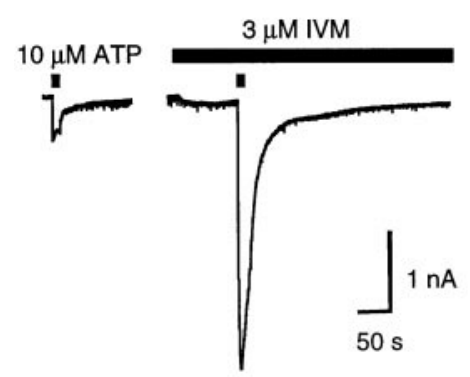

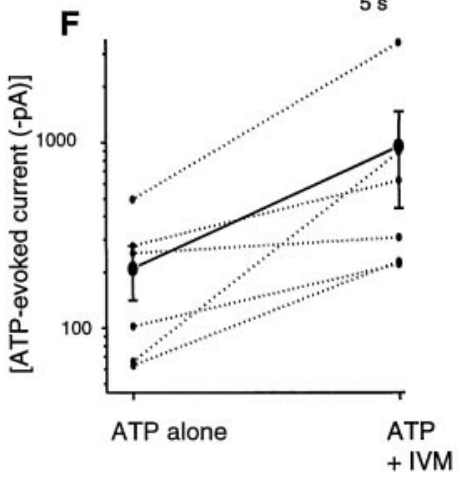

Figure 8. $\quad \mathrm{P}_{2} \mathrm{X}_{4}$ channels expressed in embryonic hippocampal neurons. $A, B$, Bright-field $(A)$ and fluorescence $(B)$ image of embryonic hippocampal neurons transfected with plasmids for $\mathrm{P}_{2} \mathrm{X}_{4}$ and EGFP. Note that the morphology of transfected and nontransected neurons is very similar, and this appearance is typical of healthy cells. The extended fluorescent cells in $B$ are glial cells. $C$, Top trace, Representative voltage-clamp currents recorded from an untransfected neuron showing no ATP-evoked currents (holding potential, $-60 \mathrm{mV}$ ); bottom trace, large ATPevoked currents in a transfected hippocampal neuron. $D$, Top trace, Representative current-clamp recording (resting potential, $-52 \mathrm{mV}$ ) from an untransfected neuron showing no ATP-evoked change in membrane potential; bottom trace, large ATP-evoked depolarization in a transfected hippocampal neuron. Action potentials have been clipped. $E$, Representative traces from a transfected hippocampal neuron showing $10 \mu \mathrm{M}$ ATP-evoked currents before and after $3 \mu \mathrm{M}$ IVM application. $F$, Summary of experiments such as those illustrated in $E$ from six neurons. Note that the size of the ATP-evoked current varies markedly between neurons, but in all neurons IVM potentiates the current. slowed its deactivation. The ATP analog $\alpha, \beta$-methylene-ATP is a weak agonist at $\mathrm{P} 2 \mathrm{X}_{4}$ channels (Buell et al., 1996) and evokes $\sim 10 \%$ of the current evoked by ATP at similar concentrations. Interestingly, however, $\alpha, \beta$-methylene-ATP and ATP both bind with relatively high affinity to $\mathrm{P}_{2} \mathrm{X}_{4}$ channels (Michel et al., 1997), suggesting that the low-potency $\alpha, \beta$-methylene-ATP in functional experiments may be attributable to a lower intrinsic efficacy or a lower ability to gate the channel once bound. In the presence of IVM, $\alpha, \beta$-methylene-ATP becomes a potent agonist, another familiar property of allosteric effectors. If further experiments lead to knowledge about the binding site and mechanisms of allosterism by IVM, this will be a useful approach to study the events leading to P2X channel gating after ATP binding.

\section{Responses in neurons}

Having established the specificity of IVM as an allosteric effector of $\mathrm{P}_{2} \mathrm{X}_{4}$ channels in oocytes, HEK cells, and embryonic hippocampal neurons, we next tested its actions in adult brain neurons that express mRNA transcripts for $\mathrm{P}_{2} \mathrm{X}_{4}$. Our initial goal was to determine whether homomeric $\mathrm{P} 2 \mathrm{X}_{4}$ channels are expressed in these neurons. In the brainstem MNV we found that IVM did not affect ATP-evoked currents, and this is consistent with previous conclusions that the $\mathrm{P} 2 \mathrm{X}$ channels in $\mathrm{MNV}$ neurons are most like $\mathrm{P}_{2} \mathrm{X}_{5}$ (Cook et al., 1997) or a combination of P2X channels (Khakh et al., 1997). The CA1 field of the hippocampus is abundant in $\mathrm{P} 2 \mathrm{X}_{4} \mathrm{mRNA}$, and previous investigators therefore suggested that homomeric $\mathrm{P} 2 \mathrm{X}_{4}$ channels might be expressed in these cells (Buell et al., 1996; Collo et al., 1996). To our surprise, IVM did not affect ATP-evoked currents in these neurons, suggesting that homomeric $\mathrm{P}_{2} \mathrm{X}_{4}$ channels are not located on the soma of pyramidal cells, but functional activity of these channels on the dendrites was not tested. To the extent that our data suggest that heteromeric $\mathrm{P} 2 \mathrm{X}_{4} / \mathrm{P} 2 \mathrm{X}_{6}$ channels are also potentiated by IVM, we may conclude that such channels are also not expressed in these cells. It is possible that the endogenous $\mathrm{P} 2 \mathrm{X}$ channels in CA1 comprise (1) other heteromeric P2X channels, (2) a mixed population of P2X channels, or (3) a new P2X channel and/or (4) that homomeric $\mathrm{P}_{2} \mathrm{X}_{4}$ channels are found in only a subset of CA1 neurons. The marked enhancement of responses in a small fraction of hippocampal neurons (Fig. $7 F$ ) is consistent with this last conclusion, but further studies are needed to discriminate between these four possibilities. Known heteromeric P2X channel assemblies are activated by $\alpha, \beta$-methylene-ATP, and it has been proposed that they may constitute some of the $\mathrm{P} 2 \mathrm{X}$ channels found in the CNS, possibly including those in the 
hippocampus (Le et al., 1998a; Torres et al., 1998, 1999). This proposal is supported by data showing overlapping distribution of many P2X subunit mRNAs throughout the nervous system (Collo et al., 1996). Interestingly, recent data from the CA1 region of the hippocampus also show that the P2X channels can be activated by $\alpha, \beta$-methylene-ATP (this study) and partially blocked by antagonists (Pankratov et al., 1998; Proctor and Dunwiddie, 1998). These properties, along with the insensitivity to IVM, suggest that the predominant ATP-evoked current (Pankratov et al., 1998) in the CA1 of the hippocampus is mediated by neither homomeric $\mathrm{P}_{2} \mathrm{X}_{4}$ nor heteromeric $\mathrm{P} 2 \mathrm{X}_{4} / \mathrm{P} 2 \mathrm{X}_{6}$ channels but rather by channels with properties that may be most similar to those described for other heteromeric channels (Lewis et al., 1995; Le et al., 1998a; Torres et al., 1998, 1999). The P2X message is not restricted to the hippocampus and is found in many brain areas (Collo et al., 1996); it remains to be determined whether some of these neuron subsets do indeed express homomeric $\mathrm{P}_{2} \mathrm{X}_{4}$ channels.

Allosteric modulators of other ligand-gated ion channels have become important experimental tools to determine the contribution of distinct channel types to the function of brain synapses. $\mathrm{P} 2 \mathrm{X}_{2}$ and $\mathrm{P} 2 \mathrm{X}_{3}$ receptors are modulated by cations such as $\mathrm{Zn}^{2+}$, $\mathrm{H}^{+}$, and $\mathrm{Ca}^{2+}$, and it is possible that such modulation has a physiological role as well (King et al., 1997; Stoop et al., 1997; Wildman et al., 1997, 1998; Cook et al., 1998). The lack of pharmacological probes for $\mathrm{P}_{2} \mathrm{X}_{4}$ channels has hindered understanding of their function, but in the present study we have identified IVM as the first agent that discriminates $\mathrm{P} 2 \mathrm{X}_{4}$ from other P2X channels. Remarkably, IVM can increase the gating efficiency and slow the deactivation kinetics of ATP at P2X channels, suggesting that the open probabilities of $\mathrm{P} 2 \mathrm{X}_{4}$ channels increase in the presence of IVM. Overall IVM evokes a profound gain-of-function phenotype in $\mathrm{P}_{2} \mathrm{X}_{4}$ channels. It remains to be determined whether the site on the $\mathrm{P} 2 \mathrm{X}_{4}$ protein that IVM probes is also the target for an endogenous allosteric effector.

\section{REFERENCES}

Bardoni R, Goldstein PA, Lee CJ, Gu JG, MacDermott AB (1997) ATP $\mathrm{P} 2 \mathrm{X}$ receptors mediate fast synaptic transmission in the dorsal horn of the rat spinal cord. J Neurosci 17:5297-5304.

Bo X, Zhang Y, Nassar M, Burnstock G, Schoepfer R (1995) A P2X purinoceptor cDNA conferring a novel pharmacological profile. FEBS Lett 375:129-133.

Buell G, Lewis C, Collo G, North RA, Surprenant A (1996) An antagonist-insensitive $\mathrm{P} 2 \mathrm{X}$ receptor expressed in epithelia and brain. EMBO J 15:55-62.

Burnstock G (1972) Purinergic nerves. Pharmacol Rev 24:509-581.

Changeux JP, Edelstein SJ (1998) Allosteric receptors after 30 years. Neuron 21:959-980.

Chen CC, Akopian AN, Sivilotti L, Colquhoun D, Burnstock G, Wood JN (1995) A P2X purinoceptor expressed by a subset of sensory neurons. Nature 377:428-431.

Collo G, North RA, Kawashima E, Merlo-Pich E, Neidhart S, Surprenant A, Buell G (1996) Cloning of P2X5 and P2X6 receptors and the distribution and properties of an extended family of ATP-gated ion channels. J Neurosci 16:2495-2507.

Collo G, Neidhart S, Kawashima E, Kosco-Vilbois M, North RA, Buell G (1997) Tissue distribution of the P2X7 receptor. Neuropharmacology 36:1277-1283.

Colquhoun D (1998) Binding, gating, affinity and efficacy: the interpretation of structure-activity relationships for agonists and of the effects of mutating receptors. Br J Pharmacol 125:924-947.

Cook SP, Vulchanova L, Hargreaves KM, Elde R, McCleskey EW (1997) Distinct ATP receptors on pain-sensing and stretch-sensing neurons. Nature 387:505-508.

Cook SP, Rodland KD, McCleskey EW (1998) A memory for extracel- lular $\mathrm{Ca}^{2+}$ by speeding recovery of $\mathrm{P} 2 \mathrm{X}$ receptors from desensitization. J Neurosci 18:9238-9244.

Cully DF, Vassilatis DK, Liu KK, Paress PS, Van der Ploeg LH, Schaeffer JM, Arena JP (1994) Cloning of an avermectin-sensitive glutamate-gated chloride channel from Caenorhabditis elegans. Nature 371:707-711.

Dunwiddie TV, Diao L, Proctor WR (1997) Adenine nucleotides undergo rapid, quantitative conversion to adenosine in the extracellular space in rat hippocampus. J Neurosci 17:7673-7682.

Edwards FA, Gibb AJ, Colquhoun D (1992) ATP receptor-mediated synaptic currents in the central nervous system. Nature 359:144-147.

Evans RJ, Derkach V, Surprenant A (1992) ATP mediates fast synaptic transmission in mammalian neurons. Nature 357:503-505.

Evans RJ, Lewis C, Virginio C, Lundstrom K, Buell G, Surprenant A, North RA (1996) Ionic permeability of, and divalent cation effects on, two ATP-gated cation channels (P2X receptors) expressed in mammalian cells. J Physiol (Lond) 497:413-422.

Fisher MH, Mrozik H (1992) The chemistry and pharmacology of avermectins. Annu Rev Pharmacol Toxicol 32:537-553.

Frazier CJ, Rollins YD, Breese CR, Leonard S, Freedman R, Dunwiddie TV (1998a) Acetylcholine activates an $\alpha$-bungarotoxin-sensitive nicotinic current in rat hippocampal interneurons, but not pyramidal cells. J Neurosci 18:1187-1195.

Frazier CJ, Buhler AV, Weiner JL, Dunwiddie TV (1998b) Synaptic potentials mediated via $\alpha$-bungarotoxin-sensitive nicotinic acetylcholine receptors in rat hippocampal interneurons. J Neurosci 18:8228-8235.

Gu JG, MacDermott AB (1997) Activation of ATP P2X receptors elicits glutamate release from sensory neuron synapses. Nature 389:749-753.

Humphrey PP, Buell G, Kennedy I, Khakh BS, Michel AD, Surprenant A, Trezise DJ (1995) New insights on P2X purinoceptors. Naunyn Schmiedebergs Arch Pharmacol 352:585-596.

Jo Y-H, Schlichter R (1999) Synaptic corelease of ATP and GABA in cultured spinal neurons. Nat Neurosci 2:241-245.

Khakh BS, Henderson G (1998a) ATP receptor-mediated enhancement of fast excitatory neurotransmitter release in the brain. Mol Pharmacol 54:372-378.

Khakh BS, Henderson G (1998b) Hyperpolarization-activated cationic currents $\left(I_{h}\right)$ in neurones of the trigeminal mesencephalic nucleus of the rat. J Physiol (Lond) 510:695-704.

Khakh BS, Humphrey PP, Surprenant A (1995a) Electrophysiological properties of P2X-purinoceptors in rat superior cervical, nodose and guinea-pig coeliac neurones. J Physiol (Lond) 484:385-395.

Khakh BS, Surprenant A, Humphrey PP (1995b) A study on P2X purinoceptors mediating the electrophysiological and contractile effects of purine nucleotides in rat vas deferens. Br J Pharmacol 115:177-185.

Khakh BS, Humphrey PP, Henderson G (1997) ATP-gated cation channels (P2X purinoceptors) in trigeminal mesencephalic nucleus neurons of the rat. J Physiol (Lond) 498:709-715.

Khakh B, Bao X, Labarca C, Lester H (1999) Neuronal P2X receptortransmitter-gated cation channels change their ion selectivity in seconds. Nat Neurosci 2:322-330.

King BF, Wildman SS, Ziganshina LE, Pintor J, Burnstock G (1997) Effects of extracellular $\mathrm{pH}$ on agonism and antagonism at a recombinant P2X2 receptor. Br J Pharmacol 121:1445-1453.

Krause RM, Buisson B, Bertrand S, Corringer PJ, Galzi JL, Changeux JP, Bertrand D (1998) Ivermectin: a positive allosteric effector of the $\alpha 7$ neuronal nicotinic acetylcholine receptor. Mol Pharmacol 53:283-294.

Krusek J, Zemkova H (1994) Effect of ivermectin on gammaaminobutyric acid-induced chloride currents in mouse hippocampal embryonic neurones. Eur J Pharmacol 259:121-128.

Le KT, Babinski K, Séguéla P (1998a) Central P2X4 and P2X6 channel subunits coassemble into a novel heteromeric ATP receptor. J Neurosci 18:7152-7159.

Le KT, Villeneuve P, Ramjaun AR, McPherson PS, Beaudet A, Seguela P (1998b) Sensory presynaptic and widespread somatodendritic immunolocalization of central ionotropic P2X ATP receptors. Neuroscience 83:177-190.

Lewis C, Neidhart S, Holy C, North RA, Buell G, Surprenant A (1995) Coexpression of $\mathrm{P} 2 \mathrm{X} 2$ and $\mathrm{P} 2 \mathrm{X} 3$ receptor subunits can account for ATP-gated currents in sensory neurons [see comments]. Nature 377:432-435. 
Li J, Zagotta WN, Lester HA (1997) Cyclic nucleotide-gated channels: structural basis of ligand efficacy and allosteric modulation. Q Rev Biophys 30:177-193.

Li YX, Zhang Y, Lester HA, Schuman EM, Davidson N (1998) Enhancement of neurotransmitter release induced by brain-derived neurotrophic factor in cultured hippocampal neurons. J Neurosci 18:10231-10240.

Michel AD, Miller KJ, Lundstrom K, Buell GN, Humphrey PP (1997) Radiolabeling of the rat $\mathrm{P} 2 \mathrm{X} 4$ purinoceptor: evidence for allosteric interactions of purinoceptor antagonists and monovalent cations with P2X purinoceptors. Mol Pharmacol 51:524-532.

Miller KJ, Michel AD, Chessell IP, Humphrey PP (1998) Cibacron blue allosterically modulates the rat P2X4 receptor. Neuropharmacology 37:1579-1586.

Nieber K, Poelchen W, Illes P (1997) Role of ATP in fast excitatory synaptic potentials in locus coeruleus neurones of the rat. Br J Pharmacol 122:423-430.

North RA (1996) Families of ion channels with two hydrophobic segments. Curr Opin Cell Biol 8:474-483.

Nuttle LC, Dubyak GR (1994) Differential activation of cation channels and non-selective pores by macrophage $\mathrm{P} 2 \mathrm{z}$ purinergic receptors expressed in Xenopus oocytes. J Biol Chem 269:13988-13996.

Pankratov Y, Castro E, Miras-Portugal MT, Krishtal O (1998) A purinergic component of the excitatory postsynaptic current mediated by $\mathrm{P} 2 \mathrm{X}$ receptors in the CA1 neurons of the rat hippocampus. Eur J Neurosci 10:3898-3902.

Proctor W, Dunwiddie T (1998) Responses to ATP application on interneurons in hippocampal brain slices show prolonged desensitization. Soc Neurosci Abstr 24:1602.

Quick MW, Lester HA (1994) Methods for expression of excitability proteins in Xenopus oocytes. In: Ion channels of excitable cells, (Narahashi T, ed), pp 261-279. San Diego: Academic.
Ralevic V, Burnstock G (1998) Receptors for purines and pyrimidines. Pharmacol Rev 50:413-492.

Seguela P, Haghighi A, Soghomonian JJ, Cooper E (1996) A novel neuronal P2x ATP receptor ion channel with widespread distribution in the brain. J Neurosci 16:448-455.

Soto F, Garcia-Guzman M, Gomez-Hernandez JM, Hollmann M, Karschin C, Stuhmer W (1996) P2X4: an ATP-activated ionotropic receptor cloned from rat brain. Proc Natl Acad Sci USA 93:3684-3688.

Stoop R, Surprenant A, North RA (1997) Different sensitivities to $\mathrm{pH}$ of ATP-induced currents at four cloned P2X receptors. J Neurophysiol 78:1837-1840.

Surprenant A, Buell G, North RA (1995) P2X receptors bring new structure to ligand-gated ion channels. Trends Neurosci 18:224-229.

Surprenant A, Rassendren F, Kawashima E, North RA, Buell G (1996) The cytolytic P2Z receptor for extracellular ATP identified as a P2X receptor (P2X7). Science 272:735-738.

Torres GE, Haines WR, Egan TM, Voigt MM (1998) Co-expression of P2X1 and P2X5 receptor subunits reveals a novel ATP-gated ion channel. Mol Pharmacol 54:989-993.

Torres G, Egan T, Voigt M (1999) Hetero-oligomeric assembly of P2X receptor subunits. Specificities exist with regard to possible partners. J Biol Chem 274:6653-6659.

Van Laethem Y, Lopez C (1996) Treatment of onchocerciasis. Drug 52:861-869.

Virginio C, Mackenzie A, Rassendren FA, North RA, Surprentant A (1999) Pore dilation of neuronal P2X receptors. Nat Neurosci 2:315-321.

Wildman SS, King BF, Burnstock G (1997) Potentiation of ATPresponses at a recombinant $\mathrm{P} 2 \times 2$ receptor by neurotransmitters and related substances. Br J Pharmacol 120:221-224.

Wildman SS, King BF, Burnstock G (1998) $\mathrm{Zn}^{2+}$ modulation of ATPresponses at recombinant $\mathrm{P} 2 \mathrm{X} 2$ receptors and its dependence on extracellular $\mathrm{pH}$. Br J Pharmacol 123:1214-1220. 